\title{
TESTING OF HNPF FREEZE-SEAL PUMP
}

$A E C$ Research and Development Report

\section{ATOMICS INTERNATIONAL}

A DIVISION OF NORTH AMERICAN AVIATION, INC. 


\section{DISCLAIMER}

This report was prepared as an account of work sponsored by an agency of the United States Government. Neither the United States Government nor any agency Thereof, nor any of their employees, makes any warranty, express or implied, or assumes any legal liability or responsibility for the accuracy, completeness, or usefulness of any information, apparatus, product, or process disclosed, or represents that its use would not infringe privately owned rights. Reference herein to any specific commercial product, process, or service by trade name, trademark, manufacturer, or otherwise does not necessarily constitute or imply its endorsement, recommendation, or favoring by the United States Government or any agency thereof. The views and opinions of authors expressed herein do not necessarily state or reflect those of the United States Government or any agency thereof. 


\section{DISCLAIMER}

Portions of this document may be illegible in electronic image products. Images are produced from the best available original document. 


\section{LEGAL NOTICE}

This report was prepared as an account of Government sponsored work. Neither the United States, nor the Commission, nor any person acting on behalf of the Commission:

A. Makes any warranty or representation, express or implied, with respect to the accuracy, completeness, or usefulness of the information contained in this report, or tha the use of any information, apperatus, method, or process disclosed in this report may not infringe privatoly owned rights; or

B. Assumes any liabilities with respect to the use of, or for damages resulting from the use of information, opparatus, method, or procass disclosed in this report.

As used in the above, "porson acting on behalf of the Commission" includes any employes or contractor of the Commission to the axtant that such emolovee or contractor prepares, handles or distributes, or provides access to, any information pursuant to his employment or confract with the Commission.

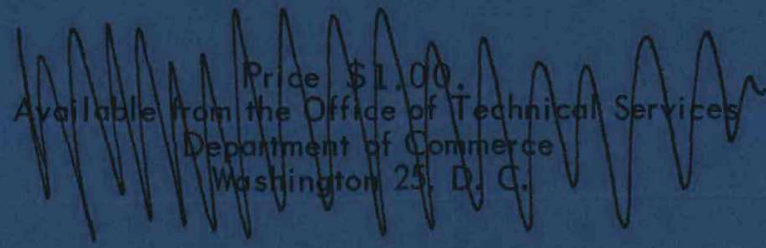




\section{TESTING OF HNPF FREEZE-SEAL PUMP}

By

R. W. ATZ

\section{ATOMICS INTERNATIONAL}
A DIVISION OF NORTH AMERICAN AVIATION, INC.
P.O. BOX 309
CANOGA PARK, CALIFORNIA

CONTRACT: AT(11-1)-GEN-8

ISSUED: NOV 1 1030 


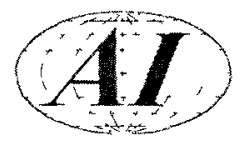

DISTRIBUTION

This report has been distributed according to the category "Reactors General" as given in "Standard Distribution Lists for Unclassified Scientific and Technical Reports" TID-4500 (15th Ed.), August 1, 1959. A total of 625 copies was printed. 
Page

Abstract .......................... v

I. Introduction. ......................... 1

II. Description of Apparatus . .................... 2

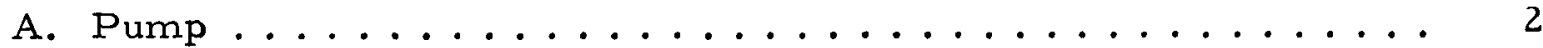

B. Pump Drive and Speed Control ................ 4

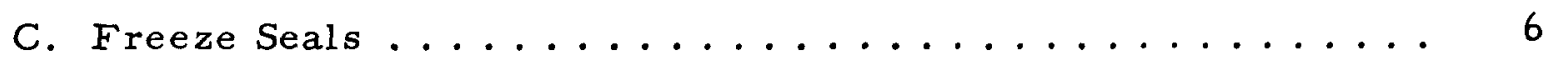

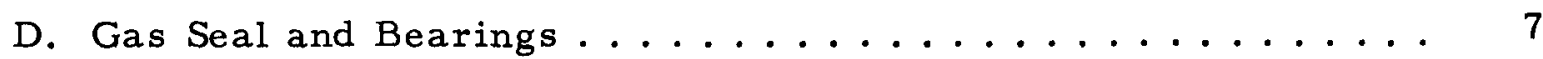

E. Test Loop, Instrumentation. ................. 7

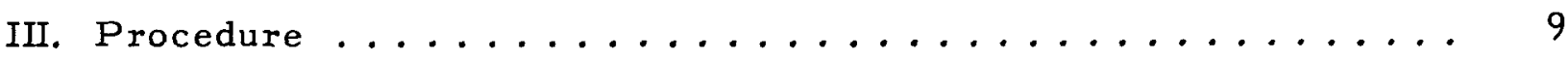

IV. Results and Discussion ...................... 12

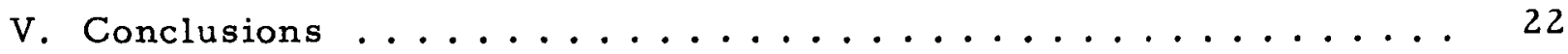

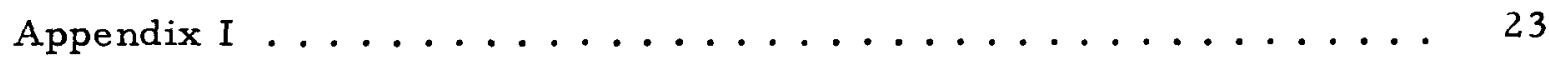

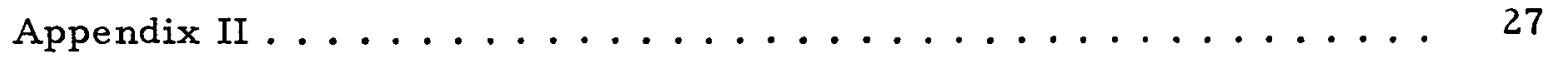

\section{TABLES}

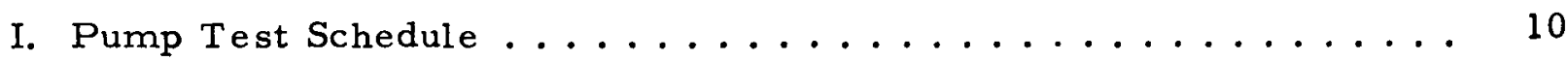

II. Pump Variables and Measurements ................ 23

FIGURES

1. Freeze-seal Pump with Motor and Variable-Speed Drive

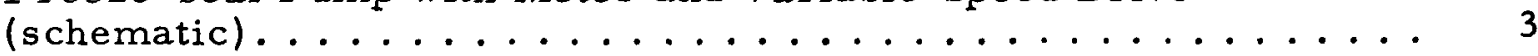

2. Internal Assembly of Freeze-Seal Pump ............... 4

3. Motor and Variable-Speed Drive................. 5

4. Two-Region Shaft Freeze Seal . . . . . . . . . . . . . . . . . . . 7

5. Head Capacity and Pump Efficiency at $835 \mathrm{rpm} \ldots \ldots . \ldots 13$

6. Head Capacity and Pump Efficiency at $417 \mathrm{rpm} \ldots \ldots . . \ldots 14$ 


\section{FIGURES}

7. Temperature Distribution in Shaft Freeze Seal .......... 15

8. Shaft-Freeze-Seal Installation and Thermocouple Location . . . . 16

9. Temperature Profile of Case Freeze Seal. . . . . . . . . . . . 17

10. Case-Freeze-Seal and Thermocouple Location . . . . . . . . . 18

lla, b, c. Three Views of Handling Fixture . . . . . . . . . . . 20

12. Freeze Seal Test Stand No. 2 (schematic) . . . . . . . . . . 29

13. Temperature Distribution in Mark III Shaft Freeze Seal . . . . . . 33

14. Seal Cooling Loads at Various Temperatures and Shaft Speeds . . . 34

15. Liquid / Solid Sodium Interface Location for Mark III Shaft

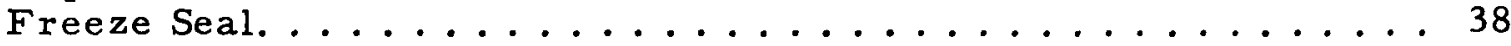

16. Gas Seal with Magnetic Faces......................42 


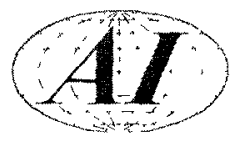

\section{ABSTRACT}

A centrifugal pump, incorporating a shaft freeze seal, was operated at the conditions required for service in the Hallam Nuclear Power Facility. The pump performed adequately at a flowrate of $7200 \mathrm{gpm}$ of $945^{\circ} \mathrm{F}$ sodium at $150 \mathrm{ft}$ head. A two-region freeze seal was developed and used successfully as a shaft seal on this pump. Results indicate that this pump could perform satisfactorily in the HNPF. 


\section{(11)}

\section{INTRODUCTION}

Centrifugal pumps, capable of pumping $7200 \mathrm{gpm}$ of $950^{\circ} \mathrm{F}$ sodium against $150 \mathrm{ft}$ head, are to be used for circulation of sodium coolant in both primary and secondary systems of the HNPF reactor. Because size and capacity of these pumps is substantially larger than those previously used in sodium service, a test program was devised to demonstrate performance of proposed units. Objectives of the program were to test two pumps of different design and to develop auxiliary components needed. A basis for design of the freeze seal pump, and its associated shaft freeze seal, was available from the results of a series of development tests on smaller pumps as well as from experience gained in use of both primary and secondary pumps at the Sodium Reactor Experiment. This report describes the testing of a freeze-seal pump; included in the appendix is the account of the development of a special shaft freeze seal for use in this pump. A separate report will cover work done on the second pump, namely the free-surface type, in which there is no shaft seal.

*R. W. Atz, NAA-SR-4336 (to be published) 


\section{(A1)}

\section{DESCRIPTION OF APPARATUS}

\section{A. PUMP}

The pump ${ }^{*}$ used for this test program was a centrifugal-diffuser type, having a nominal impeller diameter of $30 \mathrm{in.} \mathrm{Because} \mathrm{the} \mathrm{drive} \mathrm{motor} \mathrm{had} \mathrm{to}$ be mounted above radiation shielding, the pump was built with a vertical shaft $18 \mathrm{ft}$ long. Power was transmitted from the motor shaft to the pump shaft by a variable-speed eddy-current coupling. ${ }^{\dagger}$ Shown in Figure 1 are the motor and coupling housings as well as a cross section of the entire pump.

The outer casing of the pump consisted of an upper and lower part bolted together and sealed with a seal weld. The upper part of the casing was fabricated of low-carbon steel. The lower portion of the casing was made of Type 304 stainless steel; the part containing the diffuser was fabricated from two standard dished heads.

One of the design features of this pump was the removable internal assembly. This entire inner structure was supported by a heavy flange which mated with the floor plate of the outer case. The internal assembly was composed of two principal parts. The upper portion, made of carbon steel, was an annular container for the lead-shot shielding required in primary (radioactive) system pumps. This shielding container surrounded the upper part of the pump shaft. Supported below the shield container was the bearing housing which contained thrust and radial bearings for the pump. Immediately below the bearing housing assembly was the thermal barrier. This thermal barrier, constructed entirely of Type 304 stainless steel, supported the shaft freeze seal, formed a part of the case freeze seal and located the inner diffuser ring within the outer casing. All parts in contact with sodium were made of Type 304 stainless steel. The lower section of the pump shaft passed through the bearing housing into the thermal barrier and shaft freeze seal. The lower end of the shaft was tapered and keyed to accommodate the impeller. The impeller was secured to the shaft with a nut locked in place with a set screw. The impeller and diffuser were the only castings in the pump assembly. A photograph of the internal assembly is shown in Figure 2 .

* Manufactured by Byron Jackson Pump Co., Los Angeles †Manufactured by Dynamatic Div., Eaton Manf., Co., Kenosha, Wisc. 


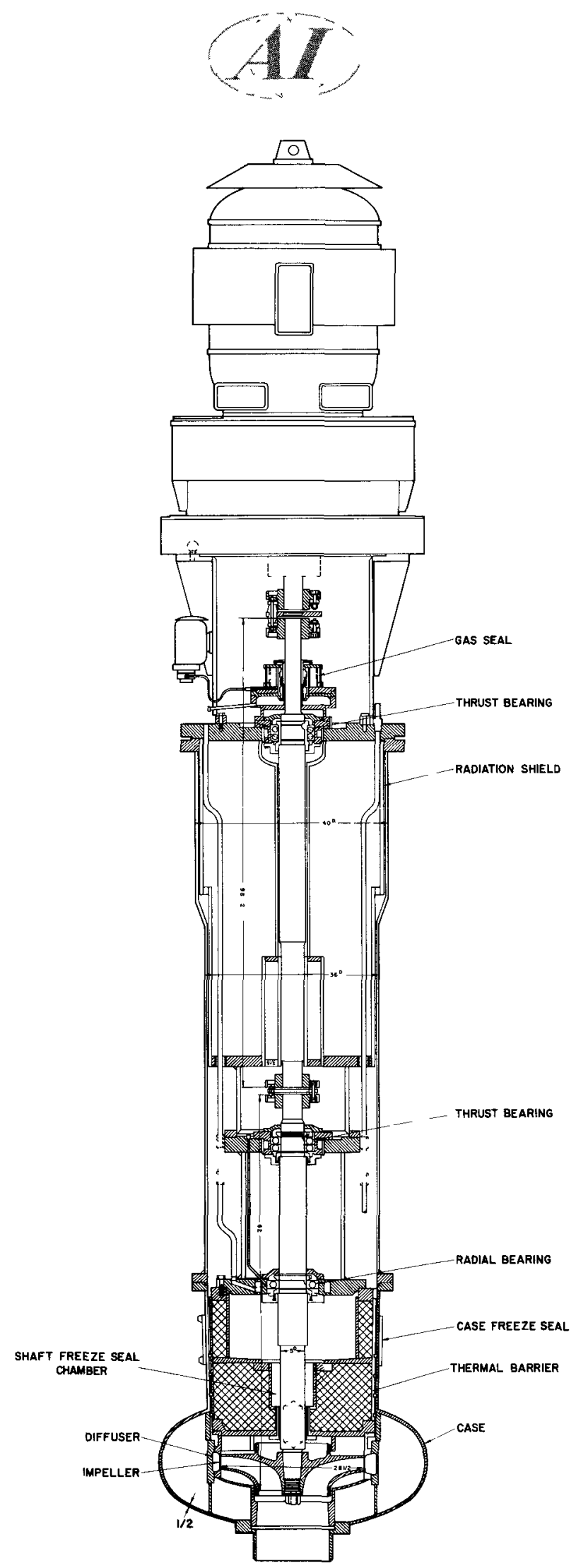

Figure 1. Freeze-Seal Pump with Motor and Variable-Speed Drive (schematic) 


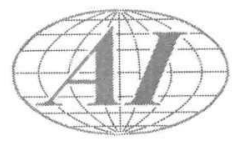

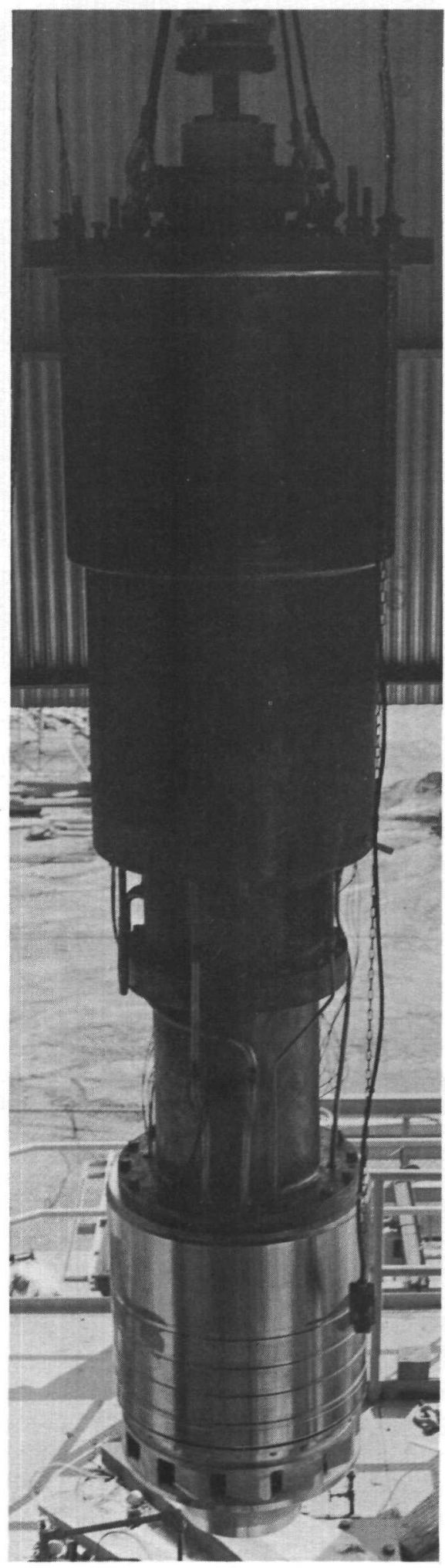

Figure 2. Internal Assembly of Freeze-Seal Pump
The thermal barrier portion of the inner assembly was sealed to the outer case by a case freeze seal. Because this seal retains sodium at full discharge pressure, the location of the seal was established to extract a minimum amount of heat and yet assure maximum protection against failure if the coolant supply were interrupted.

The case freeze-seal cooling jacket was mounted 10 in. above the point contacted by the high-temperature sodium. The jacket was 10 in. long and 1/2-in. thick. A 1/2-in.-diameter tube was wound spirally within the jacket on a $1-i n$. pitch to give guidance to the coolant. Cooled tetralin ${ }^{*}$ was circulated through the jacket.

Operating conditions for which the test pump was designed were: $7200 \mathrm{gpm}$ of $945^{\circ} \mathrm{F}$ sodium at $150 \mathrm{ft}$ head.

\section{B. PUMP DRIVE AND SPEED CONTROL}

The pump was driven by an induction motor ${ }^{\dagger}$ connected through a variable-speed eddy-current coupling (trade name: Dynamatic Drive). Shown in Figure 3 are the motor and coupling housing. The full-load speed for the motor was approximately $885 \mathrm{rpm}$; the pump-shaft speed was continuously variable from zero to a maximum of about $850 \mathrm{rpm}$.

The Dynamatic Drive comprised a driving rotor mounted on the drive-motor shaft and a drive rotor, mounted on the top of the pump shaft. Within an annular space in the driven rotor was mounted a stationary excitation coil; power to this

* Manufactured by EI DuPont de Nemours \& Co. $\dagger$ Manufactured by Allis-Chalmers Mfg. Co., Milwaukee, Wisc. 

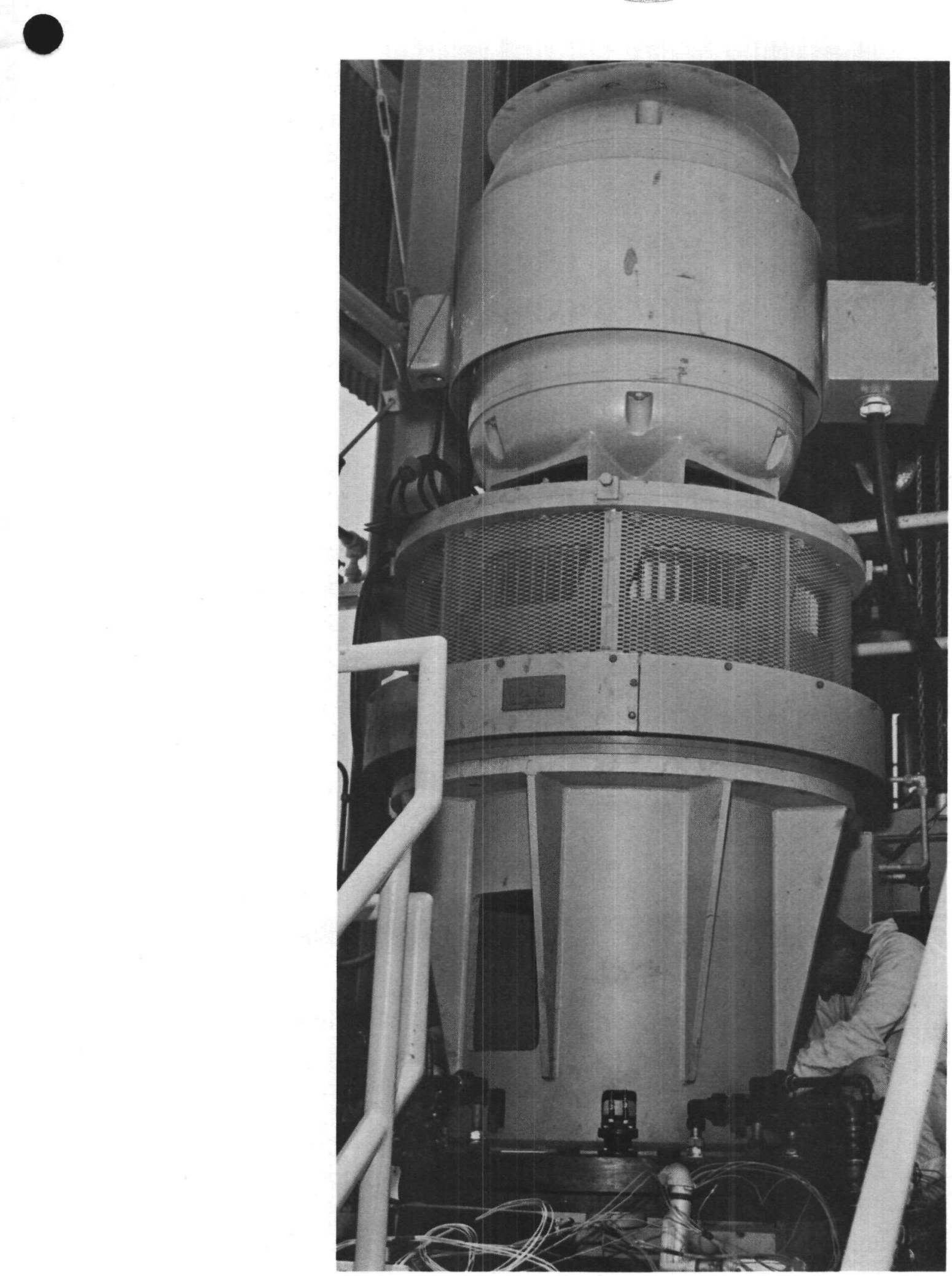

Figure 3. Motor and Variable-Speed Drive 


\section{HI}

coil effectedl a magnetic coupling force between the two rotors. Speed of the pump was changed by varying power input to the excitation coil. Heat developed in this coupling was rejected to atmosphere by a blower attached to the driving rotor.

Automatic control of the input power to the coupling was provided by a magnetic amplifier controller system. A tachometer generator mounted integrally with the eddy-current coupling generated an a-c voltage that was used by the magnetic amplifier for regulation purposes. Manual control of pump speed was done by using a rheostat switched into the control circuitry. A provision included in the speed controller, to use a voltage from magnetic flowmeter during reactor operation, was not utilized during these tests.

\section{FREEZE SEALS}

Principal developmental item within the pump was the shaft freeze seal. It was the purpose of this seal to prevent leakage of sodium up the pump shaft and to keep the cover gas out of the sodium system. Experience with the freeze seals installed in the pump at the SRE indicated several areas of potential difficulty if the same design were used for HNPF. An improved seal was developed during the period that the test pump was being built. This development is reported in Appendix I. The seal used in this pump was a two-region seal designed to operate under the following conditions: (1) bulk sodium temperatures from 350 to $945^{\circ} \mathrm{F}$; (2) sodium pressure, 10 psia; (3) shaft speeds from zero to $850 \mathrm{rpm}$; (4) inert gas pressure in the pump case of $5 \mathrm{psig.} \mathrm{The} \mathrm{seal} \mathrm{is} \mathrm{illustra-}$ ted in Figure 4.

The sodium system in the reactor is to be cold-trapped to $250^{\circ} \mathrm{F}$. It was desired, therefore, that the portion of the shaft freeze seal exposed to the flowing sodium be not colder than $270^{\circ} \mathrm{F}$ to minimize deposition of sodium oxide in the seal with the resultant scoring of the pump shaft. This was accomplished by maintaining the lowest point in the lower region of the seal at $270^{\circ} \mathrm{F}$, while concurrently maintaining the upper region at a temperature below $200^{\circ} \mathrm{F}$. A pump of this style also required a case freeze seal to prevent the flow of sodium up the outside surface of the thermal barrier into the 


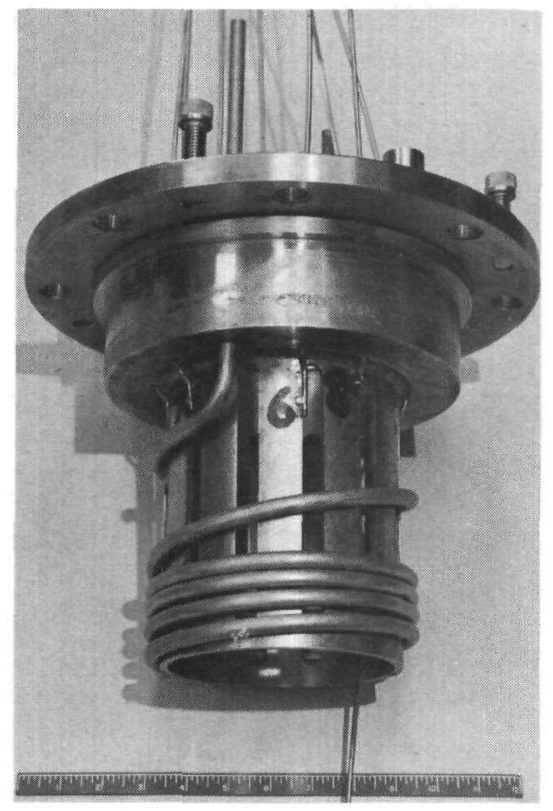

Figure 4. Two-Region Shaft Freeze Seal upper pump case. This was done by placing a cooling jacket on the outside of the pump casing. During loop filling, sodium entered the annular space between the thermal barrier and the pump casing. Coolant flowing in the jacket caused the sodium to solidify, resulting in formation of the seal.

\section{GAS SEAL AND BEARINGS}

To maintain an inert atmosphere in the pump case, a seal was required on the shaft at the point where it emerged from the upper floor plate of the pump. The seal used on this pump was a doubleface type, filled with oil which served as the sealing medium. A pump circulated oil to the seal region from an oil cooler. The seal depended upon internal

spring loading to keep the faces together to retain the oil. The pressure of the gas in the pump casing had no effect upon the operation of the seal. If a seal face failed, the oil would be forced into a reservoir below the seal housing. This chamber would keep the oil from entering the pump casing.

Standard ball bearings were used to absorb the several loads imposed on the pump shaft. These bearings were all packed with the same radiation-resistant grease ${ }^{*}$ to be used in the reactor (there was no radiation condition during the tests). All the bearings were provided with grease-filled slingers to minimize entrance of foreign materials into the races. Coolant for each bearing was admitted to annuli machined into the surrounding support structures.

\section{E. TEST LOOP AND INSTRUMENTATION}

The pump was tested in a 12-in. -pipe-size loop made of Type 304 stainless steel piping. Included in the discharge leg of the loop were a 12-in. ball-type throttling valve ${ }^{\dagger}$ and a magnetic flowmeter. An expansion tank was located near the pump suction. The total length of 12-in. piping was about $70 \mathrm{ft}$. A carbonsteel storage tank of 28.000-1b capacity was connected to the loop through 4-in. stainless steel pipe.

*Chevron Type OHT, Standard Oil Co., of California †P-K Paul Company 


\section{AI}

Coolant for the sodium freeze seals (both pump and valves) and the bearings in the pump was supplied by a circulating system which contained tetralin. Coolant supply tempe rature was maintained at $95^{\circ} \mathrm{F}$ for all uses except at the lower part of the shaft freeze seal. Both cooling circuits to the shaft freeze seal were equipped with low-flow alarms. If the coolant supply pump (or its standby) stopped, an alarm would sound, and an electrical interlock would stop the sodium pump. Heat absorbed by the coolant was given up to a cooling water system through a shell-and-tube heat exchanger.

Nitrogen was used as a cover gas in the sodium pump, the pump loop expansion tank, over the coolant system, and for pressurizing the sodium storage tank during loop filling operations.

Preheating for the storage tank, drain and fill lines, vent lines, the pump casing, and loop expansion tank was done with tubular heaters attached to the piping and the walls of the vessels. Loop piping was preheated by the transformer heating method; a low-voltage, high-amperage current was passed through the pipe to heat it to the desired temperature. The loop was electrically isolated from the support structure for this purpose. Performance of this preheating method is discussed in detail elsewhere.

Conventional variable-area flowmeters and Bourdon tube gages were used in the inert gas and coolant systems. Power to the pump drive motor and the eddy-current coupling was monitored by standard electrical meters. Sodium pressures at the pump suction and discharge were indicated by high-temperature, double-bellows-type, pressure transmitters. ${ }^{\dagger}$ The height of the sodium in the expansion tank was indicated by an inductance-coil liquid-level indicator.

Sodium flow was shown by a potentiometer reading the output from a magnetic flowmeter. All temperature measurements were made with chromel-alumel thermocouples; those inside the pump were sheathed in stainless steel.

*R. Baker and I. Villalva, "Heating Transformer Performance," NAA-SR - 4532 (to be published)

†Manning, Maxwell, and Moore, Model 185-X 


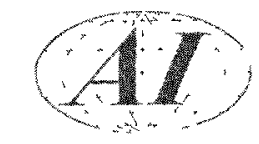

\section{PROCEDURE}

In preparation for pump performance testing, the loop piping, pump, and expansion tank were filled to an appropriate level with sodium at $350^{\circ} \mathrm{F}$. Freeze seals in the pump were established each time the loop was filled, whereas the valve-stem freeze seals were established only once, at the initial filling. After the loop system was filled, a nitrogen gas pressure of 5 psig was established in both the expansion tank and the pump case. Because power to the seal-oil pump and main drive motor was interlocked with the Dynamatic Drive circuitry, both the seal-oil pump and main drive motor had to be running before the pump could be driven. With these conditions satisfied, excitation to the eddy-current coupling coupling effected pump rotation at a speed determined by the operator. Sodium flow could be varied by adjusting either pump speed of throttle-valve position, or both.

Heat losses from the test loop were such that under average ambient conditions, energy transferred to the flowing sodium by the pump running at $800 \mathrm{rpm}$ would maintain the loop at a temperature of about $945^{\circ} \mathrm{F}$; operation of the pump at full speed caused the temperature to rise above this value. Bulk sodium heating above $350^{\circ} \mathrm{F}$ was routinely accomplished by running the pump at full speed.

During operation in the reactor, the pump will be stopped and started many times; it will pump sodium at temperatures ranging from $350^{\circ} \mathrm{F}$ to $945^{\circ} \mathrm{F}$. Pump speeds will vary from zero to $850 \mathrm{rpm}$. A test schedule (Table I) was followed to simulate all reactor operating conditions (except radiation). Data were obtained so that head-capacity curves could be derived from the pump at the operating conditions described in Table I. Simultaneously, equilibrium temperature data within the pump were taken to observe the effect of the variations in operation conditions upon the shaft freeze seal, case freeze seal, and the bearings.

Performance of an equilibrium test was accomplished by:

a) Heating the sodium to the specified temperature (by varying the pump speed);

b) Adjusting the pump speed to the proper value; and

c) Varying the sodium flow over the range from zero to the maximum attainable within the capability of the pump. 
TABLE I

PUMP TEST SCHEDULE

\begin{tabular}{|c|c|c|}
\hline Test Number & $\begin{array}{l}\text { Sodium } \\
\qquad\left({ }^{\circ} \mathrm{F}\right)\end{array}$ & $\begin{array}{l}\text { Pump Speed } \\
\text { (xpm) }\end{array}$ \\
\hline 1 & 350 & 83.5 \\
\hline 2 & 350 & 200 \\
\hline 5 & 350 & 835 \\
\hline 12 & 600 & 200 \\
\hline 15 & 600 & 835 \\
\hline 21 & 900 & 83.5 \\
\hline 22 & 900 & 200 \\
\hline 23 & 900 & 417.5 \\
\hline 24 & 900 & 800 \\
\hline 25 & 900 & 835 \\
\hline 26 & 900 & 851 \\
\hline 32 & 945 & 200 \\
\hline 33 & 945 & 417.5 \\
\hline 34 & 945 & 800 \\
\hline 35 & 945 & 835 \\
\hline 36 & 945 & 851 \\
\hline 41 & 1000 & 83.5 \\
\hline 42 & 1000 & 200 \\
\hline 43 & 1000 & 417.5 \\
\hline 44 & 1000 & 800 \\
\hline 45 & 1000 & 835 \\
\hline 46 & 1000 & 851 \\
\hline
\end{tabular}


Generally, six to eight different flowrates were recorded during a particular test.

Recorded continuously during each test were the sodium bulk temperatures, pump bearing temperatures, and all the temperatures in the freeze seals. Information was taken from these indicating (but nonrecording) instruments at each value of sodium flow:
a) Sodium pump suction and discharge pressure transmitters
b) Sodium flowmeter
c) Sodium-bulk temperature indicator
d) Drive-motor kilowatt meter, ammeter, ard voltmeter
e) Eddy-current clutch excitation voltage and current meters
f) Tachometer indicator
g) Change in temperature across the seal cooling circuits
h) Bulk coolant temperature
i) Coolant flowrates to the freeze seals. 


\section{(AI)}

\section{RESULTS AND DISCUSSION}

Head-capacity and pump-efficiency curves are presented in Figures 5 and 6 for full- and half-speed conditions. The calculations and calibration curves used to derive these performance curves are in Appendix I. Corresponding data obtained from water tests performed by the vendor are shown on the curves for comparison purposes.

Although tests were conducted for all conditions listed in Table I, erratic operation of the sodium pressure transmitters prevented obtaining reliable head and capacity data in all tests.

Efficiency curves in Figures 5 and 6 are for the particular head-capacity curves shown. In other tests, the efficiencies were much closer to those obtained in the water tests. The reason for these discrepancies is believed to have been faulty electrical-power metering equipment. The total running time for the test was 960 hours.

The only auxiliary component that could have affected operation of the pump was the shaft freeze seal. The shaft freeze seal imposed a small braking action upon the pump shaft. The power to drive the shaft in the freeze seal was too small to be of significance when compared to the horsepower input to the pump drive motor. Heat lost from the pump by the use of the freeze seals was approximately $4.6 \mathrm{kw}$ at the full design operating conditions.

Performance of the two-region shaft freeze-seal was monitored throughout the test program. Temperature distribution along the shaft through the seal is shown in Figure 7. A detailed drawing of the shaft freeze seal is shown in Figure 8. Very little attention by the operators was required, because the seal functioned properly with constant coolant flowrates to both seal regions.

Operation of the case freeze seal required a constant flow of $2 \mathrm{gpm}$ of coolant to the cooling jacket. During the test, readings of the thermocouples in the case freeze seal were recorded. A typical temperature profile along the seal is shown in Figure 9. A detail sketch of the freeze seal is shown in Figure 10. 


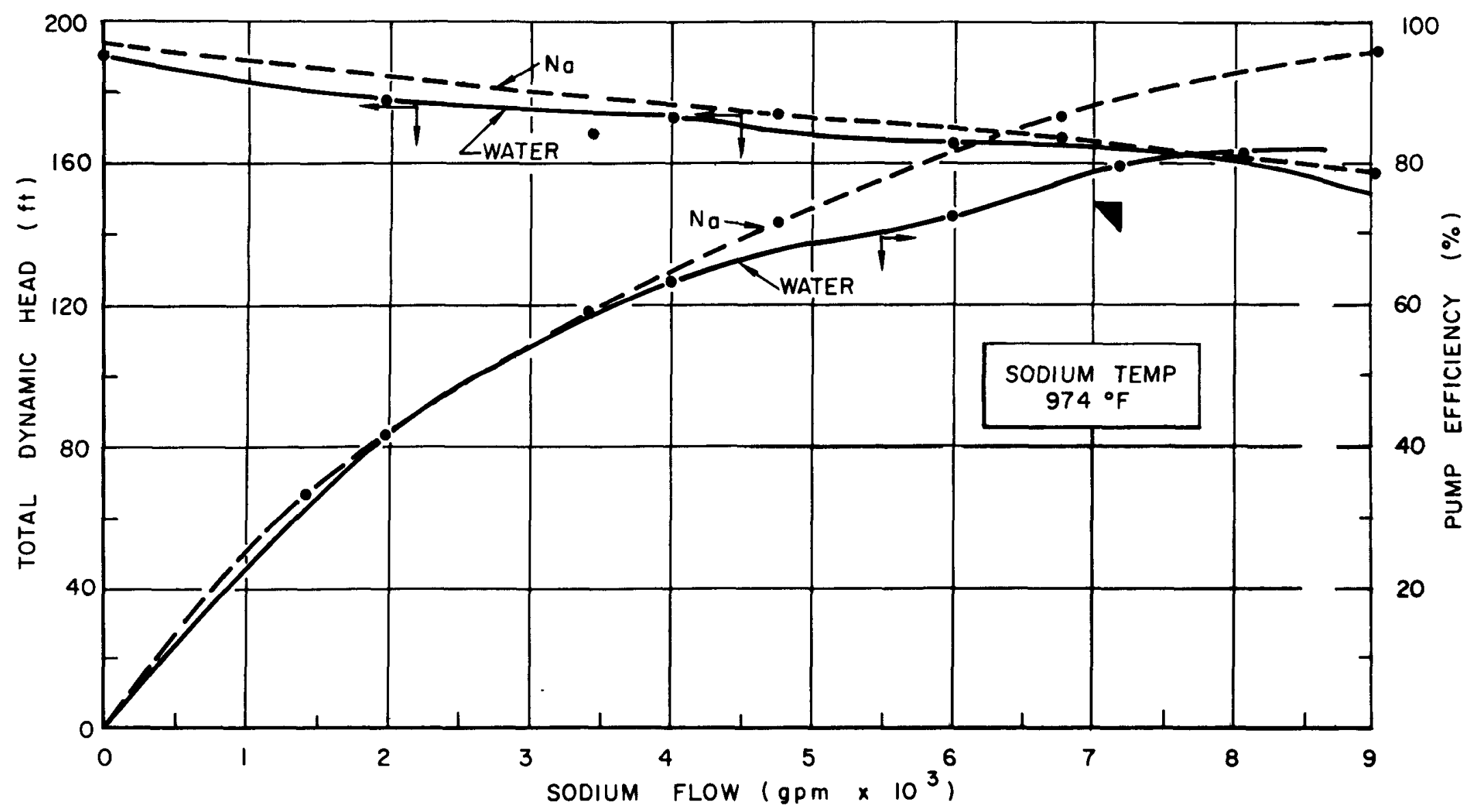

Figure 5. Head Capacity and Pump Efficiency at $835 \mathrm{rpm}$ 


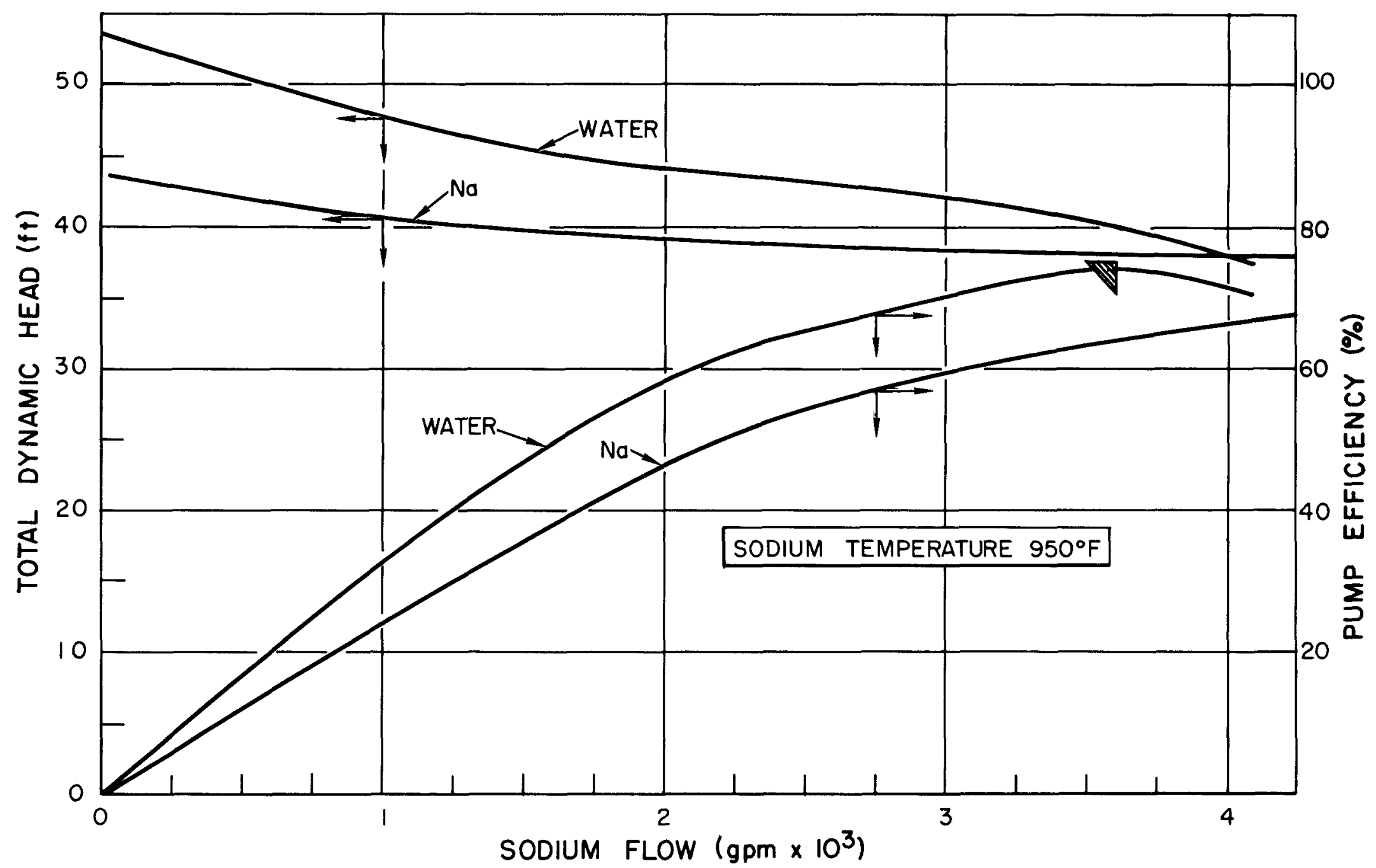

Figure 6. Head Capacity and Pump Efficiency at $417 \mathrm{rpm}$ 


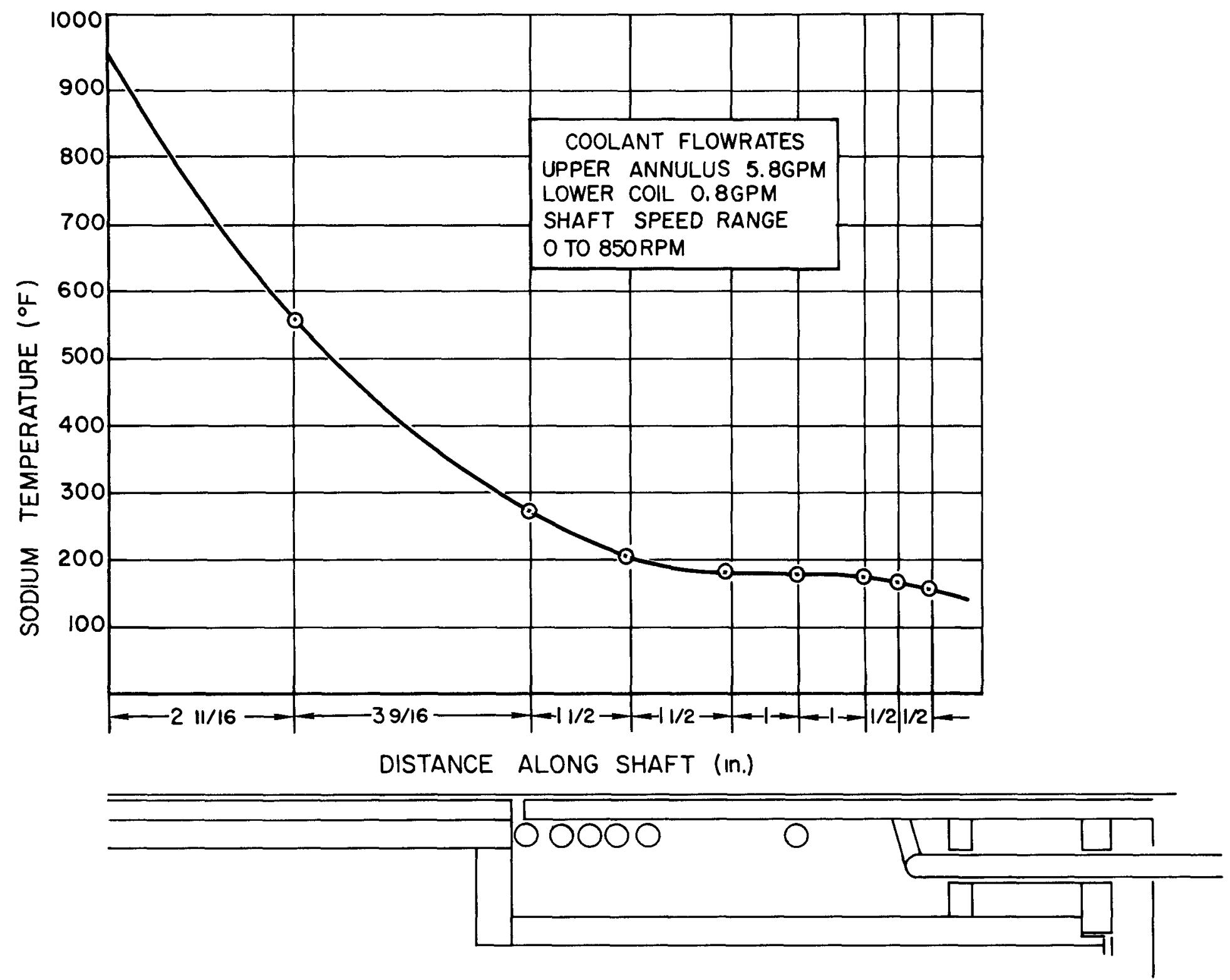

Figure 7. Temperature Distribution in Shaft Freeze Seal 


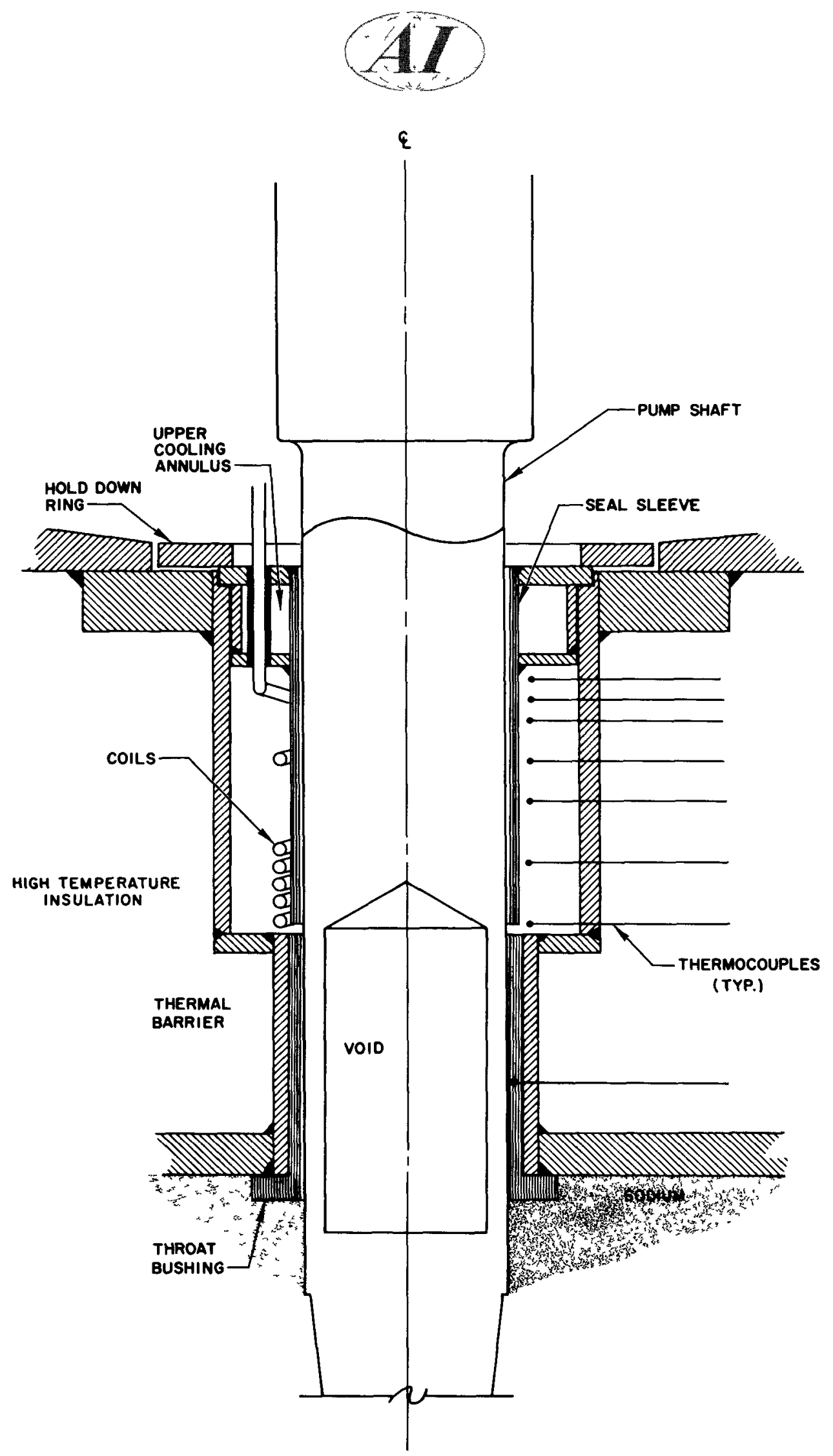

Figure 8. Shaft-Freeze-Seal Installation and Thermocouple Location 


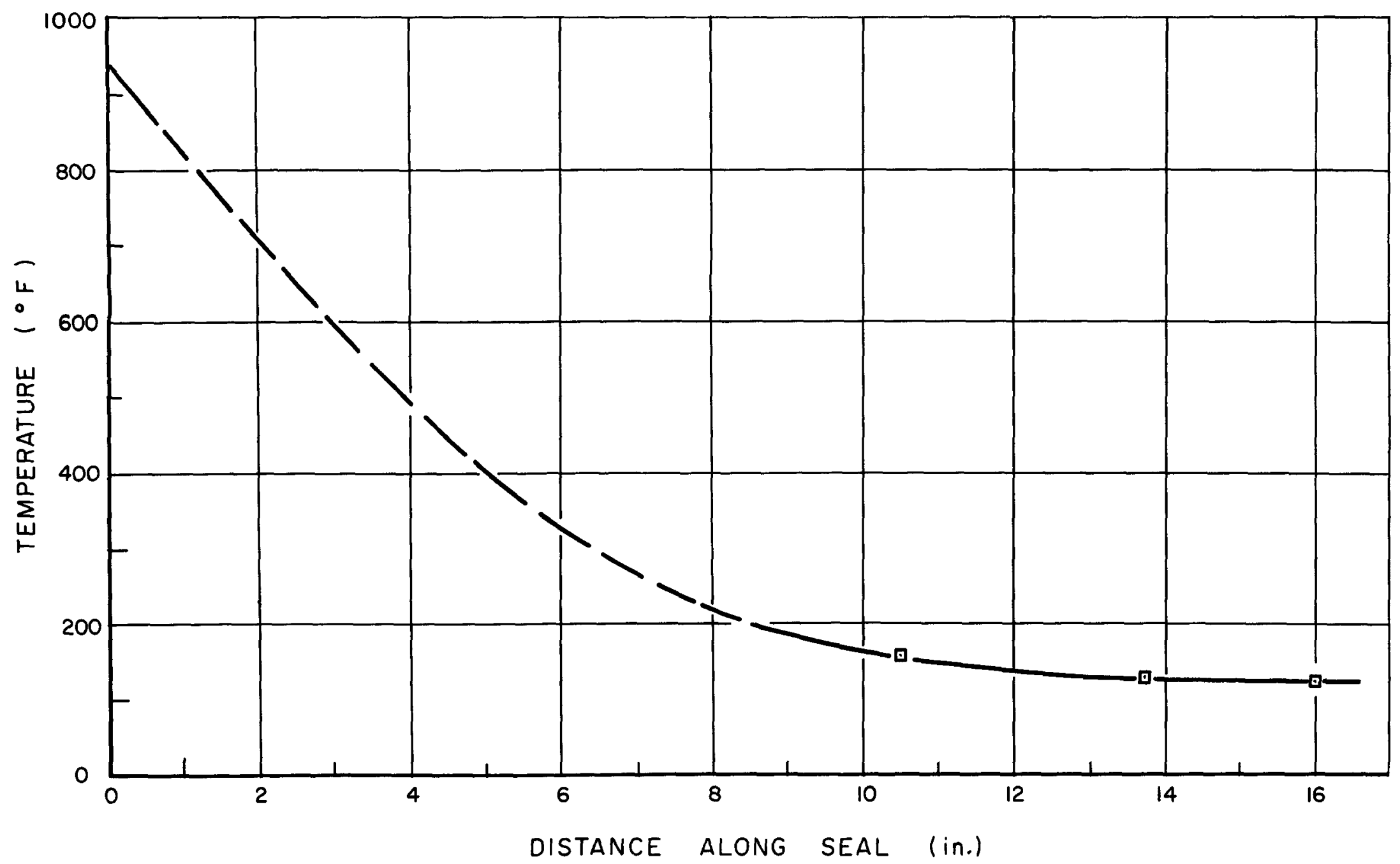

Figure 9. Temperature Profile of Case Freeze Seal 


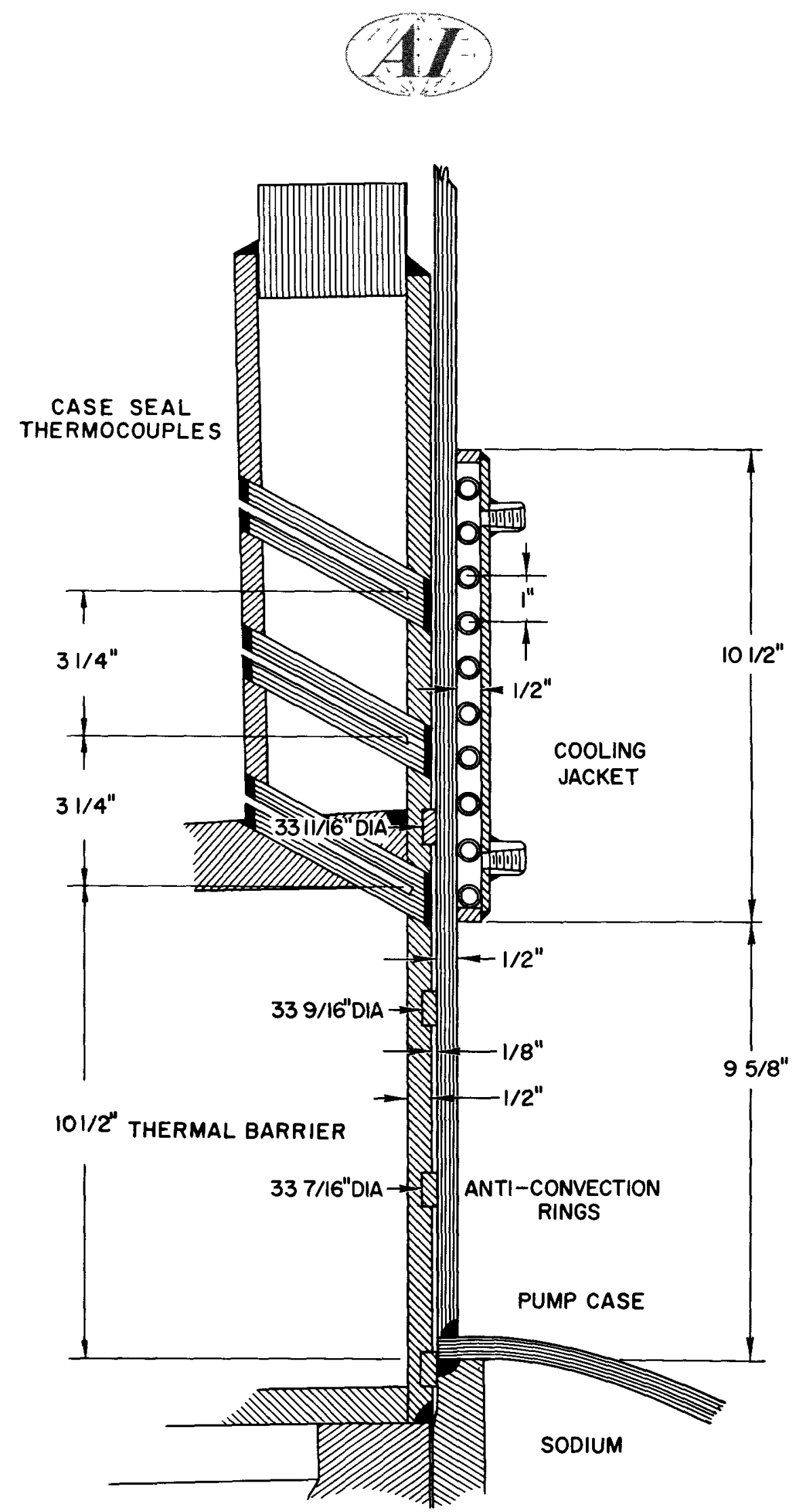

Figure 10. Case-Freeze-Seal and Thermocouple Location 


\section{(AI)}

Besides extracting heat from the 1/8-in. -wide sodium-filled annulus between the thermal barrier and the pump casing, the case freeze seal retained the discharge pressure developed by the pump. At no time during the test program did the seal temperatures reach levels that would indicate a failure.

The gas seal operated satisfactorily, requiring little attention during the entire test program. Oil in the seal (30 W tubrine oil) reached a maximum temperature of $160^{\circ} \mathrm{F}$ when the pump shaft speed was $850 \mathrm{rpm}$. Because this was considered too high a temperature, an oil cooler was installed in the circulating loop which reduced the maximum temperature of the seal and the oil to $120^{\circ} \mathrm{F}$. There was no need to add oil to the seal throughout the test program after the initial filling, which required 1.5 quarts.

Successful operation of the pump was aided by the trouble-free service of the pump bearings. During water tests of the pump at the vendor's plant the bearings were operated without coolant. During the sodium testing the thrust and radial bearings in the bearing housing were cooled with $0.5 \mathrm{gpm}$ of $95^{\circ} \mathrm{F}$ coolant. (Use of coolant was mainly a precautionary measure to help keep sodium from entering the radial bearing in event of a shaft seal failure.) The maximum (and equilibrium) bearing temperature of $120^{\circ} \mathrm{F}$ attained was at a shaft speed of $850 \mathrm{rpm}$.

A separate bearing test program was performed to optimize the class of bearing fit and to verify the suitability of the grease retaining shields for bearings of the size required. Data from the se tests were used in the installation of the bearings in the pump; the pump bearings were installed with an 0.0005 - to 0.0006-in. interference fit on the shaft and an 0.0001- to 0.000-in. interference fit in the housing. During this test program the se bearings were run at speeds to $900 \mathrm{rpm}$. Although no coolant was used on these bearings, the temperatures did not exceed 10 degrees more than the ambient.

A corollary activity in the experimental program was the study of handling requirements of the pump. A handling fixture was built to facilitate assembly of the pump and for steam cleaning the inner assembly. The handling fixture is shown in Figure $11 \mathrm{a}$. The pump was also shipped from the vendor's plant in the fixture. Upper and lower parts of the pump assembly are shown mounted in Figures $1 \mathrm{lb}$ and $1 \mathrm{lc}$ respectively. Most of the components of the pump were 


\section{(411)}
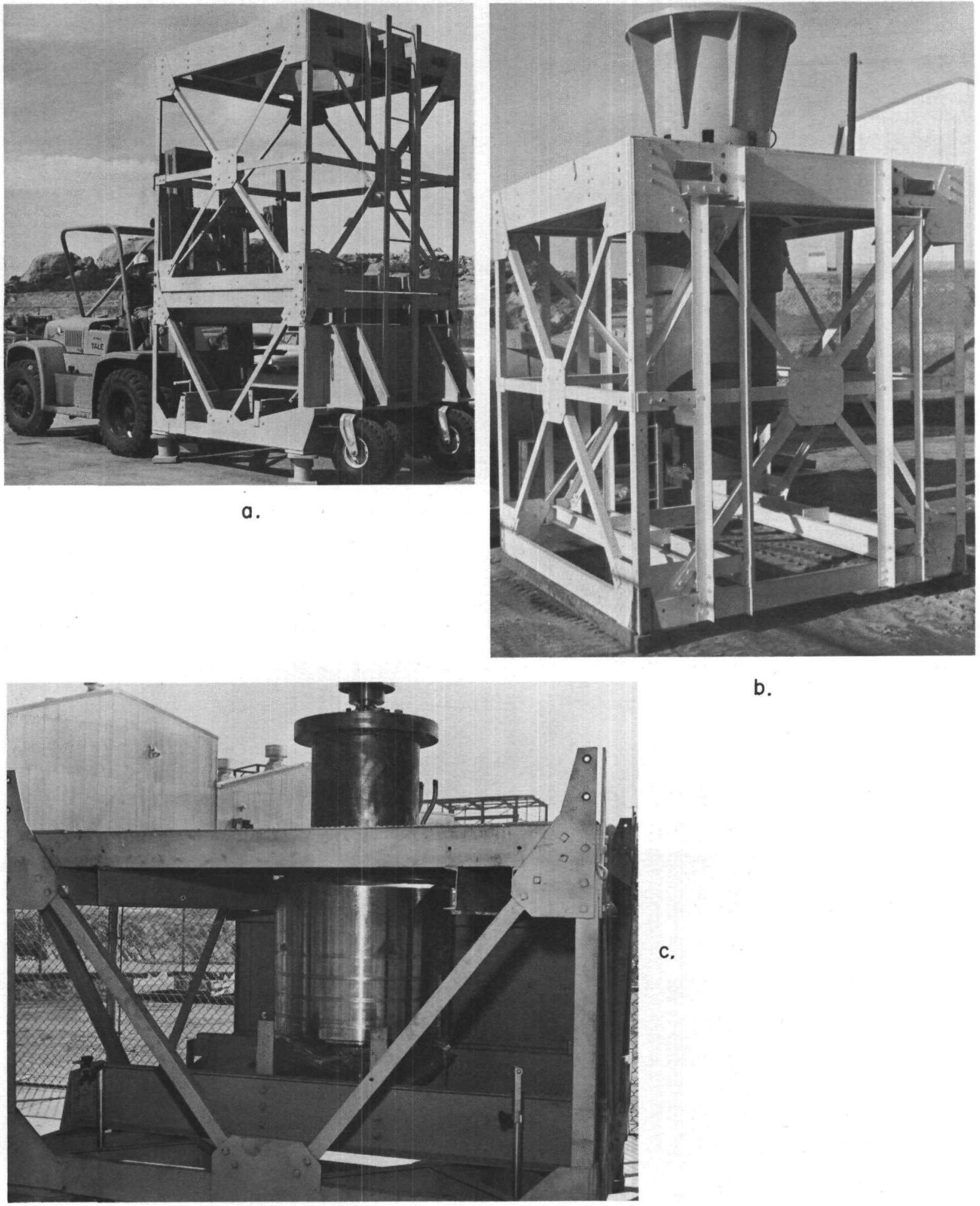

b.

c.

Figure 1la, b, c. Three Views of Handling Fixture 


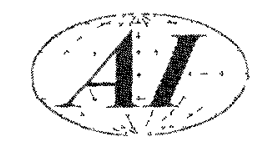

with ordinary slings and hooks. A special shackle was required to lift the drive motor and eddy-current clutch which were always handled assembled as a unit.

The inner assembly was removed from the outer casing on two occasions, first to repair the radial bearing cover, and again at the conclusion of the test program. In both instances the use of tapped holes for jack screws facilitated disassembly and reassembly of the pump. After the final cleaning and dismantling of the pump assembly, the radial bearing was found to be free of sodium and the grease in slingers above and below the bearing was intact. There was no evidence of excessive wear anyplace in the assembly. 


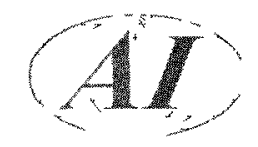

\section{v. CONCLUSIONS}

Results of the test program demonstrated that the pump was capable of operating satisfactorily over a wide range of conditions.

Performance of the shaft freeze seal was satisfactory. However, the shaftfreeze-seal configuration was not completely optimized. A further refinement of the shaft-freeze-seal installation would have resulted in a shorter thermal barrier and a smaller heating requirement for the seal.

The performances of the case freeze seal, the packed grease bearings, and the gas seal were satisfactory. 


\section{(1)}

\section{APPENDIX I}

\section{SAMPLE CALCULATION OF HEAD_CAPACITY CURVES}

Derivation of the head capacity and pump efficiency curves are described in this section. Variables measured, their means of measurement, and their probable accuracy are shown in Table II.

A sample calculation is given below. Similar calculations were performed for all the plotted points on the pump performance curves.

Taking the sodium flow as the independent variable, the head developed by the pump and the pump efficiency were plotted on coordinate axes as shown in Figures 5 and 6.

TABLE II

PUMP VARIABLES AND MEASUREMENTS

\begin{tabular}{l|l|c}
\hline \multicolumn{1}{c|}{ Item } & \multicolumn{1}{c|}{ Readout } & $\begin{array}{c}\text { Estimated } \\
\text { Accuracy } \\
(\%)\end{array}$ \\
\hline Pump shaft speed (rpm) & Strobotac & $1 / 4$ \\
Sodium temperature ( $\left.{ }^{\circ} \mathrm{F}\right)$ & Thermocouple & 2 \\
Sodium pressure (psig) & $\begin{array}{l}\text { Manning, Maxwell } \\
\text { \& Moore Transmitters }\end{array}$ & 2 \\
Sodium flow, read as mv & Rubicon potentiometer & 5 \\
Pump motor power (kw) & G. E. panel meter & 2 \\
\hline
\end{tabular}

Using the test point of $6800 \mathrm{gpm}$ flow from Figure 5 as an example, the other necessary experimental data were:

Pump shaft speed (rpm) 635

Sodium bulk temperature $\left({ }^{\circ} \mathrm{F}\right) \quad 974$

Pump suction pressure (psig) 4.1

Pump discharge pressure (psig) $\quad 37.0$

Sodium flowmeter ( $\mathrm{mv}$ ) 29.2

Power to drive motor (kw) 83 


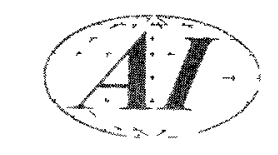

With sodium at $974^{\circ} \mathrm{F}$, a flowmeter signal output of $29.2 \mathrm{mv}$ equals $5160 \mathrm{gpm}$.

The total dynamic hear represents the sum of the differential head, the elevation head and the contraction loss across the pump.

The differential head, $P_{1}$, (in feet) equals the pump discharge less the pump inlet pressure.

$$
\begin{gathered}
P_{1}=P_{\text {out }}-P_{\text {in }}=37.0-4.1-32.9 \mathrm{psi} \\
P_{1}(\mathrm{ft})=32.9 \frac{\mathrm{lb}}{\mathrm{ft}^{2}} \times 144 \frac{\mathrm{in}}{\mathrm{ft}^{2}} \times \frac{1}{51.7} \mathrm{lb} / \mathrm{ft}^{3}=91.6 \mathrm{ft},
\end{gathered}
$$

where $51.7 \mathrm{lb} / \mathrm{ft}^{3}$ is the density of sodium at $974^{\circ} \mathrm{F}$.

The elevation head, $P_{2}$, is the distance between the centerline of the pump suction line and centerline of the pump discharge line. In this instance, $\mathrm{P}_{2}$ equals $4.0 \mathrm{ft}$.

The contraction loss across the pump, $P_{3}$, is credited to the head developed by the pump. The pump has a 16-in. suction nozzle and a 14-in. discharge nozzle. The contraction head is derived as follows:

$$
\begin{aligned}
\text { Pipe Size } & \frac{\mathrm{V}^{2}}{2 \mathrm{~g} \mathrm{ft} / 1000 \mathrm{gpm}} \\
14-\text { in. } & 0.0874 \\
16 \text {-in. } & \frac{0.0512}{0.0362 \mathrm{ft} / 1000 \mathrm{gpm}}
\end{aligned}
$$

The contraction head loss, $P_{3}$, at $5160 \mathrm{gpm}$ equals

$$
0.0362\left(\frac{5160}{1000}\right)^{2}=0.96 \mathrm{ft}
$$

Therefore, the total dynamic head is $91.6 \mathrm{ft}+4.0 \mathrm{ft}+0.96 \mathrm{ft}=96.56 \mathrm{ft}$ at $5160 \mathrm{gpm}$. 


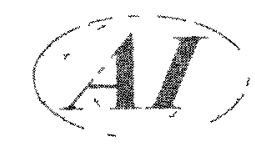

The pump efficiency is the ratio of the hydraulic horsepower developed by the pump to the brake horsepower input to the pump.

The hydraulic horsepower developed by the pump is calculated as follows:

$$
h p=\frac{\frac{\text { gal }}{\min } \times \text { total dynamic head ft }}{33,000 \frac{\mathrm{ft}-1 \mathrm{~b}}{\mathrm{~min}} \text { per } \mathrm{hp} \times \frac{\mathrm{lgal}}{8.33 \mathrm{lb}}} \times \mathrm{sp} \mathrm{gr} \text { of sodium. }
$$

For the point under consideration:

$$
\mathrm{hp}=\frac{5160 \frac{\mathrm{gal}}{\mathrm{min}} \times 96.56 \mathrm{ft}}{33,000 \frac{\mathrm{ft}-\mathrm{lb}}{\mathrm{min}} \text { per hp } \times \frac{1 \mathrm{gal}}{8.33 \mathrm{lb}}} \times \frac{51.7 \frac{\mathrm{lb}}{\mathrm{ft}^{3}}}{62.4 \mathrm{lb} / \mathrm{ft}^{3}}=104.6 \mathrm{hp} .
$$

The horsepower input to the pump is calculated as follows:

$$
\mathrm{hp} \text { to drive motor }=\frac{\mathrm{kw} \text { to drive motor }}{0.746 \mathrm{kw} / \mathrm{hr}} \times \text { meter multiplier (1.75). }
$$

For the point under consideration:

$$
\mathrm{hp} \text { to drive motor }=\frac{83}{0.746} \times 1.75=194 \mathrm{hp} \text {. }
$$

The drive motor efficiency was taken from vendor's data. The combined efficiency of the motor and the coupling is calculated from the relationship:

$$
\text { Unit Efficiency }=\text { Motor Efficiency } \times \frac{\text { Speed of Pump }}{\text { Speed of Motor }} \text {. }
$$

Motor speed as a function of load was also taken from vendor's data.

For $194 \mathrm{hp}$ input to the motor the motor efficiency is $91.5 \%$ and the motor speed is $895 \mathrm{rpm}$. The efficiency of the unit is then:

$$
91.5 \times \frac{635}{895}=62.4 \%
$$


The horsepower input to the pump equals $194 \times 0.624=121 \mathrm{hp}$, and the pump efficiency becomes $\frac{104.6}{121}=86.3 \%$.

For the purposes of plotting, the flow and the head developed are converted to a constant speed, $835 \mathrm{rpm}$ in this instance. The change in pump efficiency with speed is ignored. This is done as follows:

$$
\frac{Q_{1}}{Q_{2}}=\frac{S_{1}}{S_{2}} \quad ; \quad \frac{H_{1}}{H_{2}}=\left(\frac{S_{1}}{S_{2}}\right)^{2}
$$

where $Q_{1}$ represents the flow, gpm at the shaft speed $S_{1} \cdot H_{1}$ describes the head developed in feet at the shaft speed $S_{1}$, in rpm.

$$
\begin{aligned}
& Q_{1}=5160 \mathrm{gpm} \times \frac{835 \mathrm{rpm}}{635 \mathrm{gpm}}=6800 \mathrm{gpm}, \\
& H_{1}=96.56 \mathrm{ft} \times\left(\frac{835 \mathrm{rpm}}{635 \mathrm{rpm}}\right)^{2}=167 \mathrm{ft} .
\end{aligned}
$$

The inaccuracies in the instruments shown in Table II have a small effect upon the performance curve. The principal source of error appears to be the variations possible in the 12-in. magnetic flowmeter. As an example, the flow at $5160 \mathrm{gpm}$ could be 5120 to $5200 \mathrm{gpm}$. The effect of this change in flow is hardly noticeable upon the head-capacity curve. 


\section{(4I)}

\section{APPENDIX II \\ PUMP COMPONENT DEVELOPMENT}

\section{SHAFT FREEZE SEAL}

\section{A. INTRODUCTION}

The principal criterion for satisfactory operation of the shaft freeze seal required the maintenance of a constant temperature distribution in the length of solid sodium in the seal under all combinations of pump operating conditions. This temperature profile described the location of the liquid-to-solid interface and the temperatures existing through the length of the thermal barrier. A basis for the configuration of the shaft freeze seal was available from previous experience in development of the freeze seal pump for the Advanced SGR Program. It was on this program that the concept of the two-coolant-region coil-type seal was developed. The difference in sealing requirements for the HNPF lay in the size of the shaft being sealed, and the speed of the pump. Previous experience was limited to 3 -in. - diameter shafts running at $1200 \mathrm{rpm}$. The shaft in the HNPF prototype pump was 5 in. in diameter and rotated at $835 \mathrm{rpm}$.

The seal was required to prevent leakage of sodium into the pump case under all normal operating conditions of the pump; i. e. bulk sodium temperatures from 350 to $945^{\circ} \mathrm{F}$, and shaft speeds from 0 to $835 \mathrm{rpm}$. A value for differential pressure across the seal was arbitrarily taken at 10 psi. A method of seal operation was to be determined which would prevent shaft seizure at low rotative speeds.

The seal was also required to prevent gas in the pump casing from leaking into the sodium in the pump. It was also desired that the seal should not act as a cold trap and that it be fail-safe in the event of coolant-flow interruption.

\section{B. SUMMARY}

Three prototype, two-coolant-region shaft freeze-seals were tested under simulated reactor service conditions, to determine their operating characteristics. Information obtained included: 1) ability of the seal to retain sodium under all conditions of pump operation; 2) heating load on seal coolant at various shaft speeds and bulk sodium temperatures; and 3) temperature distribution along the length of the seal under several different combinations of conditions. 


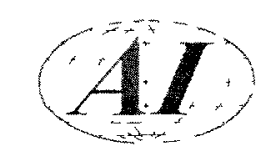

It was found that the two-region freeze seal operated satisfactorily only when the lower of the two regions received heat from the fluid (tetralin) circulated through it. With the inlet temperature of coolant to the upper region of the seal maintained at $95^{\circ} \mathrm{F}$ and that to the lower region held in the range of 240 to $285^{\circ} \mathrm{F}$, the seal functioned satisfactorily for 1100 hours.

In the case where $95^{\circ} \mathrm{F}^{*}$ coolant was circulated through both sections of the seal, excessive cooling occurred; this resulted in either improper formation of the seal or in seizure of the shaft when rotative speed was low. It was also found in this case that the cooling load on the seal varied directly with both shaft speed and bulk sodium temperature. The maximum cooling load of $2.56 \mathrm{kw}$ occurred at a shaft speed of $840 \mathrm{rpm}$ and with a bulk sodium temperature of $1000^{\circ} \mathrm{F}$.

The first two seals tested did not fulfill all the operating requirements and were discarded. The third seal satisfactorily met all conditions before being installed in the pump.

\section{DESCRIPTION OF EQUIPMENT}

1. Test Rig

The experimental work was performed in two successive series of tests, each of which is reported here.

The freeze seal test stand, shown schematically in Figure 12, consisted of a simulated pump case with case freeze seal, a thermal barrier and throat bushing, and a bearing housing which supported the shaft. The shaft used was hollow, 4-in. ID and 5-in. OD, in the length of the seal region. An electromagnetic pump was used to circulate the sodium through the system, and flows were measured with a magnetic flowmeter. Heat was added to the sodium by a 36-kw immersion heater. A surge tank was incorporated which could be pressurized with helium gas to force the sodium into the pump case and impress a differential pressure $(\triangle P)$ across the seal. A gas-pressure reducing station was supplied for controlling sodium leve in the system. A pressure applied on

\footnotetext{
* The coolant supply temperature specified for the HNPF.
} 


\section{AI}

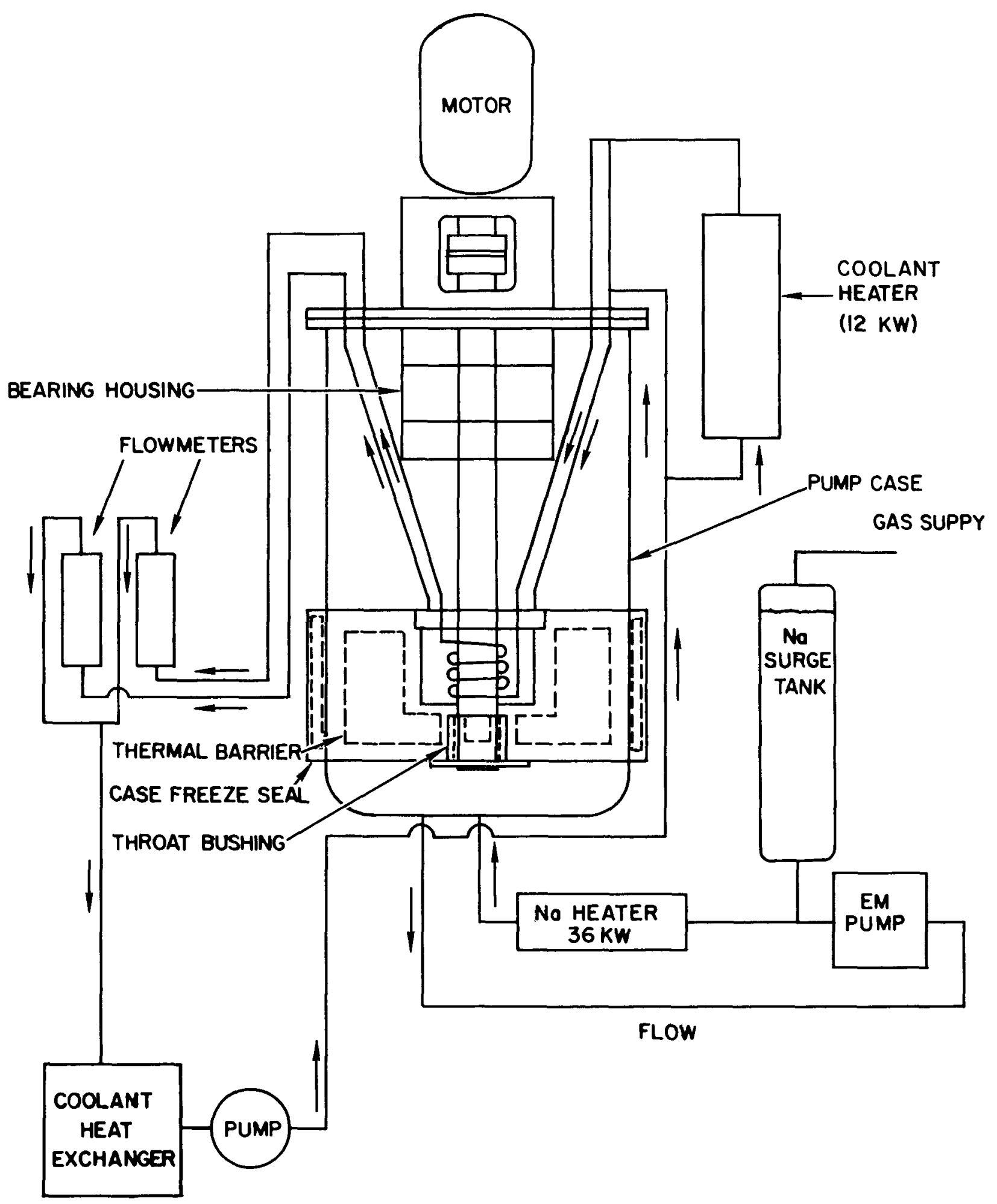

Figure 12. Freeze Seal Test Stand No. 2 (schematic) 


\section{(AI)}

the surge tank caused the sodium level to rise into the seal. A pressure applied to the pump case above the seal could be used to reduce sodium level in the seal or to force sodium which had leaked past the seal back into the system. (Sodium leakage past the seal occurred only while manipulating sodium during drain and fill operations or while melting a frozen shaft seal). The normal setting of pressures in these two chambers resulted in the $10 \mathrm{psi} \Delta \mathrm{P}$ required across the seal.

The tetralin heater shown in Figure 12 was added for use during the second series of tests. Input power to this $12-\mathrm{kw}$-capacity immersion heater was controlled by a stepless transformer. The heated liquid was piped only to the lower region of the shaft freeze seal.

\section{Freeze Seals}

Three two-region shaft seals, basically of the same design, but different in detail, were used in the development tests. Common to all three was the design of the upper region seal, namely a 2 -in.-long annular chamber concentric with the simulated pump shaft. This chamber contained an axial divider to assure complete circulation of the coolant. The lower region of the three seals differed and must be separately described.

The lower region of the first seal (Mark I) used in initial tests (which are not reported here) was only 4-1/2-in. long, in which there were six turns of 1/2-in. -OD by 0.035-in. -wall stainless steel coolant tubing. The six turns were evenly spaced over the lower 3-1/2-in. of the seal length.

The lower region of the second seal (Mark II) used in the first series of tests reported here was 6-1/2 in. long, and there were eight turns of 1/2-in. - OD by 0.035-in. -wall stainless steel tubing coiled around a slotted sleeve. The coils were evenly spaced over the lower 5 in. of the seal length.

In the case of the final seal (Mark III) used in the second series of tests reported here, the number of coils in the lower region of the seal was reduced to six. The tubing size was reduced to $3 / 8-i n$. OD by $0.035-i n$. wall in order to increase the coolant velocity through the coils. Five of the tubing coils were concentrated at the bottom of the 6-1/2-in. -long skirt, and only one turn was widely spaced from them in the upper part of the skirt (see Figure 4). 


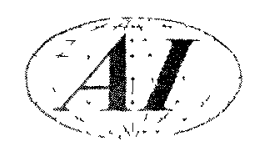

\section{Instrumentation}

All temperature measurements were obtained with chromel-alumel stainless-steel-sheathed thermocouples recorded on conventional instruments. Location of thermocouples in the seal can be seen in Figure 4. Coolant differential temperature measurements $(\Delta t)$ were made with differential thermocouples connected to a slide-wire potentiometer.

Shaft speed measurements were all obtained with a Strobatac.

\section{METHOD USED}

\section{General}

Because of the number of mutually dependent variables entering into operation of the shaft freeze seal, a statistically designed test program was established for each of the two test series reported here. It was the aim of the statistical design to optimize the number of data points to be recorded. With a given freeze seal in place, a seal was established in the usual manner, and tests were conducted over a range of shaft speeds, coolant flows, and bulk sodium temperatures as dictated by individual runs specified in the test program.

\section{First Test Series}

\section{a. Method}

In this test series the effort was directed towards the determination of the cooling load on the shaft seal. A general expression was formulated for the heat removed from the seal as a function of the three variables mentioned in the previous paragraph. Data from test runs were used in a multiple correlation (utilizing an IBM 709) which resulted in determination of coefficients to be used in the expression to obtain seal cooling loads.

Had the seal performed as expected, the location of the liquid/solid interface within the seal length would also have been determined as a function of the other operating variables. Location of the interface was taken to be between thermocouples which indicated temperatures spanning the $208^{\circ} \mathrm{F}$ value; in this series the interface was always below the bottom of the seal skirt. 
The freeze seal was established as follows: 1) flow of coolant $\left(95^{\circ} \mathrm{F}\right)$ was started in the upper region of the seal; 2) the shaft was rotated between $1 / 2$ and 3/4 of full speed; and 3) the surge tank was pressurized to raise the sodium (at about $350^{\circ} \mathrm{F}$ ) level into the seal. Formation of the seal was assumed complete when a sudden decrease in shaft speed occurred.

Having established the seal, the shaft speed, coolant flows, and bulk sodium temperatures were adjusted to the values required.in individual test runs.

\section{a. Results}

The test data indicated that the liquid/solid interface was always located in the throat bushing below the seal when coolant was circulated through both regions of the seal. The total heat available from shearing friction and conduction along the shaft, throat bushing, and thermal barrier was insufficient to keep the seal molten in the lower region. (Or conversely, the cooling capacity of the seal was too great). No combination of conditions was obtained that allowed the solid/liquid interface to rise into the seal region. This condition was intolerable because it brought about two situations adversely affecting pump operation: 1) at low shaft speeds the extra length of frozen sodium resulted in shaft seizure, and 2) the freeze-seal section acted as an oxide cold trap resulting in scoring of the shaft.

The principal results of these tests are shown in the typical curves of Figures 13 and 14. Curves A, C, and D of Figure 13 show that the temperature was essentially constant through both regions of the seal. The separation between curves $A$ and $B$ is due to the different in coolant flow, that between $A$ and $D$ is due to friction heat generated by shaft rotation, and that between $A$ and $C$ is the sum of effects occasioned by shaft rotation and bulk sodiurn temperature differences occurring at the extremes of operating conditions. A greater coolant flowrate yielded a temperature gradient, curve $B$, though the slope was not as great as desired, and the temperature was low enough to result in shaft seizure when the shaft speed was reduced. 


\section{(AI)}
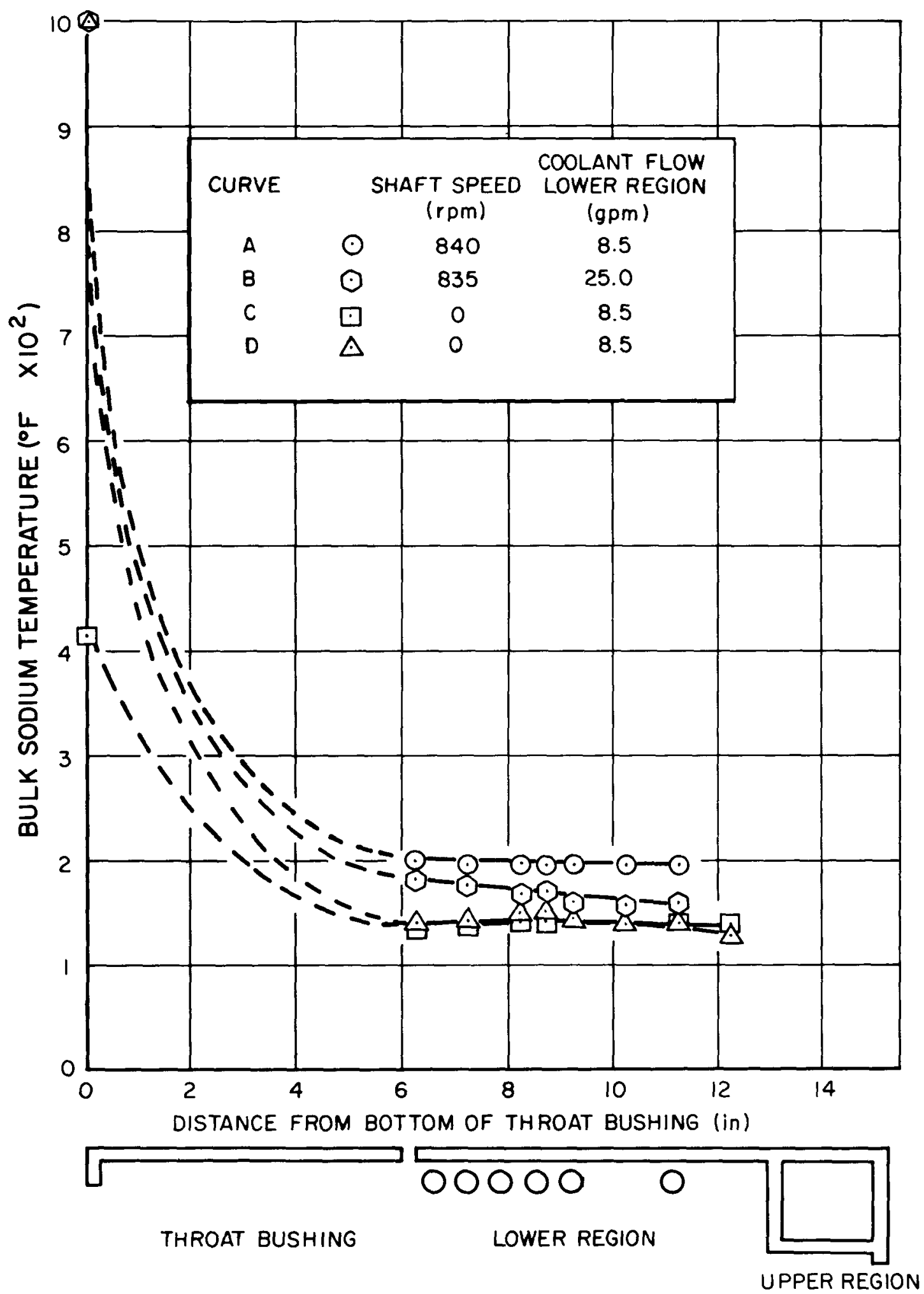

Figure 13. Temperature Distribution in Mark III Shaft Freeze Seal 


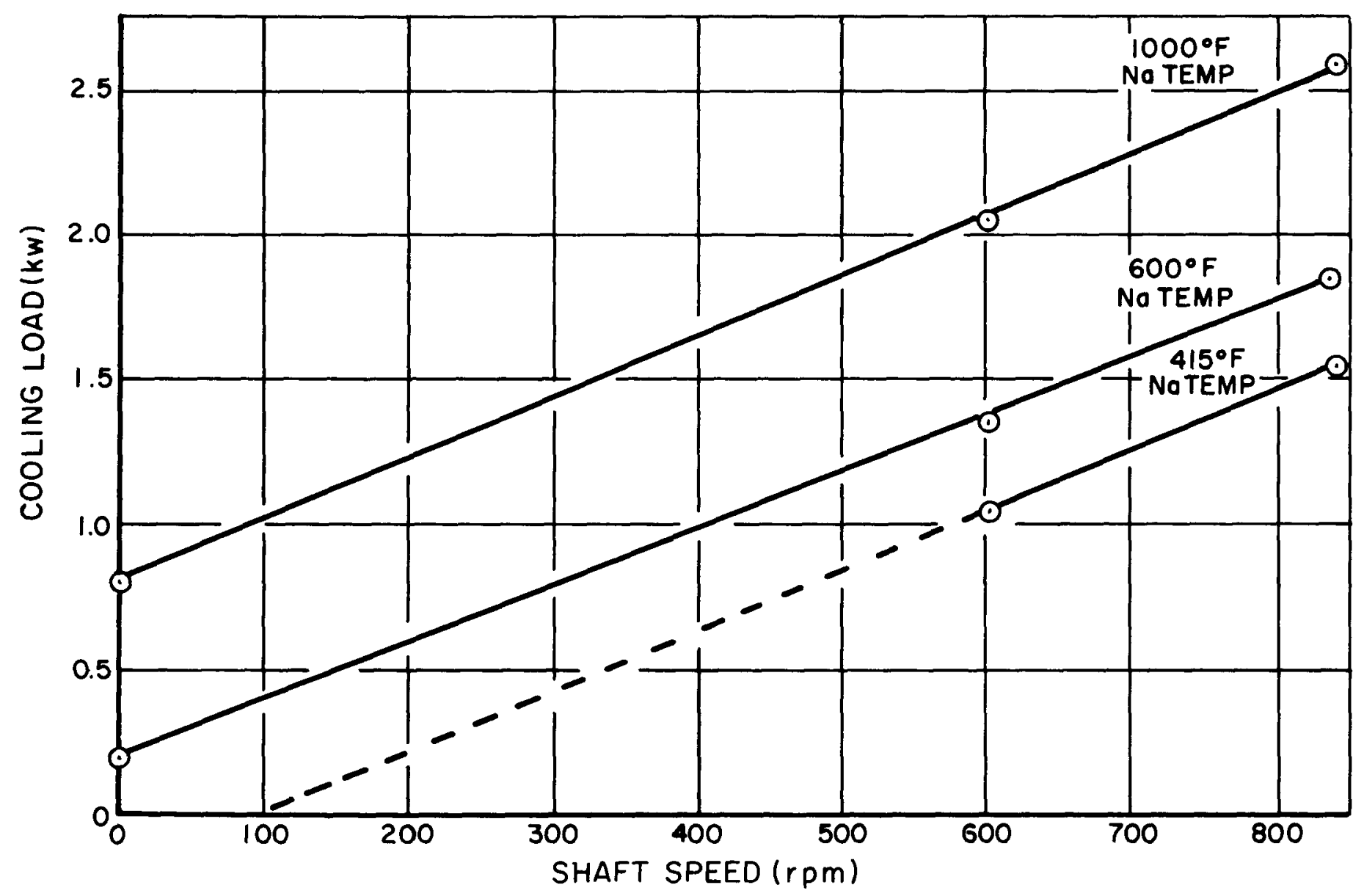

Figure 14. Seal Cooling Loads at Various Temperatures and Shaft Speeds 


\section{(AI)}

Cooling loads were calculated using the equation shown below. The results of these calculations show the cooling load on the shaft to be linear with shaft speed and to increase with the increase of bulk sodium temperatures (see Figure 14). The sample calculation below was made for approximate HNPF design operating conditions.

$$
H R=A T_{N A}+D S+C_{W C}+D
$$

where

$$
\begin{aligned}
\mathrm{T}_{\mathrm{NA}} & =\text { sodium bulk temperature, } 1008^{\circ} \mathrm{F} \\
\mathrm{S} & =\text { shaft speed, } 835 \mathrm{rpm} \\
\mathrm{WC} & =\text { coolant flow rate; } 0.48 \mathrm{gpm} \text { (lower region) }
\end{aligned}
$$

$A, B, C$, and D constants.

$$
\begin{aligned}
\mathrm{HR} & =(1008 \times 0.0953)+(840 \times 0.1197)+(0.48 \times 57.2186)+(-78.461) \\
& =145.85 \mathrm{Btu} / \mathrm{min}
\end{aligned}
$$

$$
\mathrm{kw}=\frac{\mathrm{Btu} / \mathrm{hr}}{3413}=\frac{60 \times 145.85}{3413}=2.56 \mathrm{kw} .
$$

\section{c. Discussion}

In all previous use of two-region freeze seals, as well as in all runs of this test series, coolant at a temperature well below the melting point of sodium was supplied to both regions of the seal. The combination of the thermal barrier, throat bushing, hollow shaft, and seal configuration used here resulted in excessive cooling, too great a length of frozen sodium, and ultimately in shaft seizure. In consideration of the several remedial actions that could be taken, it was suggested that the temperature of the coolant to the lower region of the seal be increased above the melting point of sodium. This idea was adopted and led to the next series of tests. 


\section{Second Series}

\section{a. Method}

An immersion heater was added to the coolant system so that the temperature of the fluid circulated through the lower seal region could be automatically maintained at about $250^{\circ} \mathrm{F}$. Because heat was added to the lower seal region, while being removed from the upper region, the parameter of cooling load on the seal was no longer of any concren. Therefore, the statistical design of tests for the second series was directed toward establishing the location of the liquid-solid sodium interface under the range of operating conditions previously stipulated. An expression relating interface position and operating variables was established, data were correlated to obtain proper coefficients, and test sequences for obtaining optimum coolant flows and temperatures were established.

The initial effort in this second series of tests was to establish the optimum flows necessary to maintain the seal under widely varying conditions of operation. The limits of operation were taken to be 0 to $835 \mathrm{rpm}$ and 450 to $1000^{\circ} \mathrm{F}$. Flow to the lower region of the seal was fixed at $0.2 \mathrm{gpm}$ and the temperature at $280^{\circ} \mathrm{F}$, while operating at maximum shaft speed and bulk sodium temperature $\left(835 \mathrm{rpm}, 1000^{\circ} \mathrm{F}\right)$. By varying coolant flow to the upper region, it was determined that $5.8 \mathrm{gpm}$ of $95^{\circ} \mathrm{F}$ coolant was required to keep the sodium frozen in the upper region of the seal under these conditions. Next, the flow to the upper region of the seal was fixed at $5.8 \mathrm{gpm}$ while operating at minimum shaft speed and sodium temperature $\left(0 \mathrm{rpm}, 450^{\circ} \mathrm{F}\right)$. By varying the coolant flow to the lower region, it was determined that $0.8 \mathrm{gpm}$ of 240 to $285^{\circ} \mathrm{F}$ liquid were required to keep the lower region of the seal at $270^{\circ} \mathrm{F}$ under these conditions. Since $5.8-\mathrm{gpm}$ tetralin flow was required to keep the upper region frozen at maximum heat conditions, and $0.8 \mathrm{gpm}$ of coolant was sufficient to keep the lower region molten at minimum heat conditions, it can be seen that this combination of flows and temperatures are adequate for all conditions. Having determined the necessary flowrate/temperature conditions, additional tests were then performed to determine the location of the liquid/solid sodium interface over the full range of coolant flowrates to the lower region, shaft speeds, and bulk sodium temperatures. 


\section{(AI)}

Optimum operating conditions for this two-region seal were concluded to be as follows:

1) A flowrate of $5.8 \mathrm{gpm}$ of $95^{\circ} \mathrm{F}$ coolant should be supplied to the upper region of the seal.

2) A flowrate of $0.8 \mathrm{gpm}$ of 240 to $285^{\circ} \mathrm{F}$ liquid should be supplied to the lower (coil) region of the seal.

3) The temperature at the bottom of the seal should be maintained at $270^{\circ} \mathrm{F}$. (See comments about this under the section on discussion.)

The heater in the coolant circuit was controlled by a signal from a thermocouple in the lower region of the seal. As the bulk sodium temperature or shaft speed was increased, the temperature at the bottom of the seal increased. This increase in temperature signaled the stepless transformer to decrease the liquid inlet temperature. The relatively low temperature of the incoming liquid then reduced the temperature at the bottom of the seal until the system reached a new equilibrium.

\section{b. Results}

Results of these tests are presented in a series of curves (Figure 15) which indicate the location of the liquid/solid interface at various operating conditions. Observing Figure 15, it may be seen that at maximum design operating conditions it is possible to operate the seal with no liquid flow to the lower region of the seal. However, if the seal were operated in this manner, and the pump speed or sodium bulk temperature were reduced, it would be necessary to reestablish liquid flow through the lower region of the seal. This relatively cool liquid might cause freezing of the seal sodium and possibly result in shaft seizure.

The curves in Figure 15 were based upon an equation obtained from statistical analysis of the data. The sample calculation below was made at approximate HNPF design operation conditions:

$$
x=A S+B T_{n a}+C Q_{c s}+D
$$




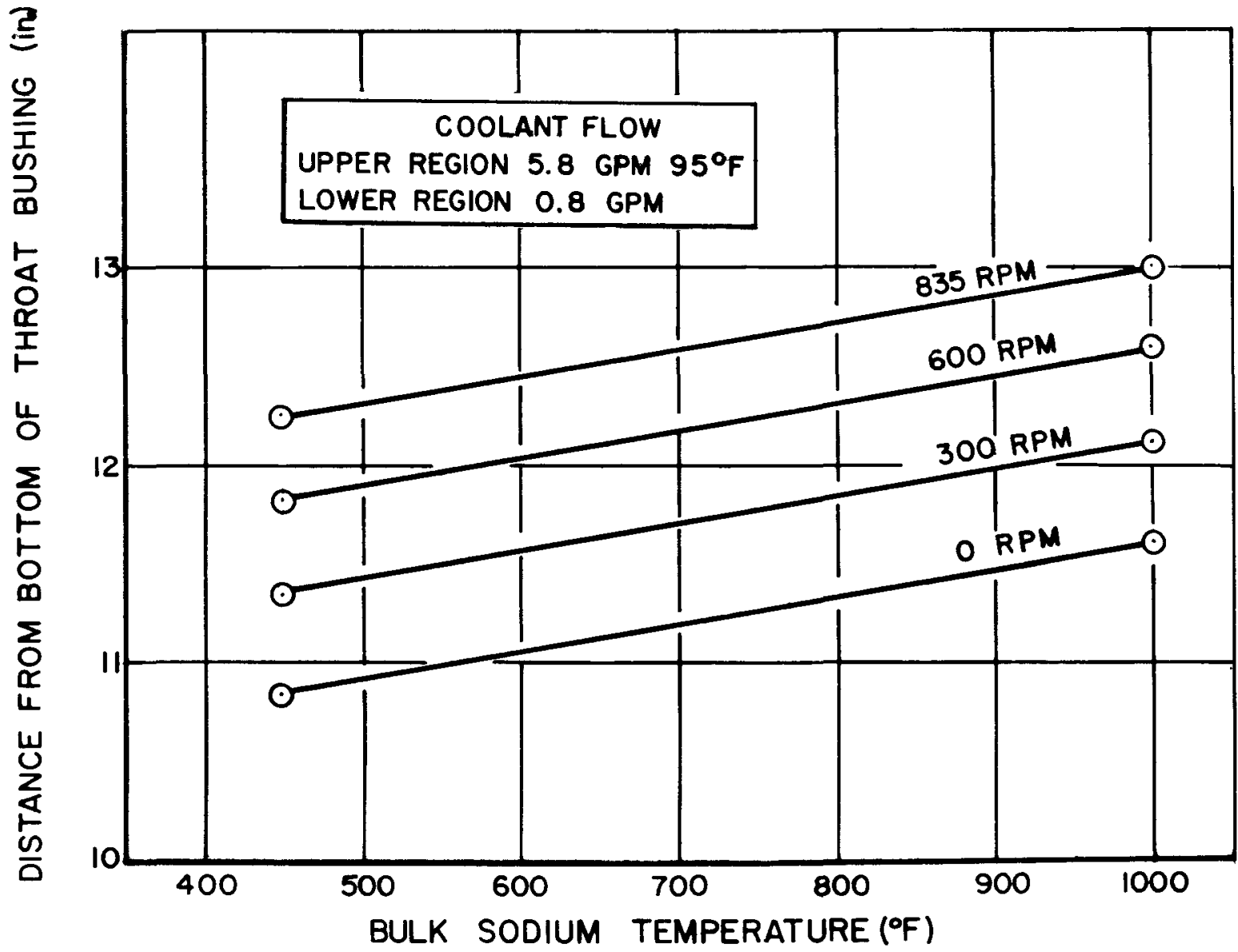

Figure 15. Liquid/Solid Sodium Interface Location for Mark III Shaft Freeze Seal 


\section{(AI)}

where

$$
\begin{aligned}
& \mathbf{x}=\text { location of the liquid/solid interface below the flange (in.) } \\
& \mathrm{S}=\text { shaft speed, } 835 \mathrm{rpm} \\
& \mathrm{T}_{\mathrm{NA}}=\text { sodium temperature, } 945^{\circ} \mathrm{F} \\
& Q_{C S}=\text { liquid flow to lower region, } 0.8 \mathrm{gpm} \\
& \text { and } \mathrm{A}, \mathrm{B}, \mathrm{C}, \text { and } \mathrm{D} \text { are constant. }
\end{aligned}
$$

Thus

$$
\begin{aligned}
\mathbf{x} & =3.7128-(0.001661 \times 835)-(0.001436 \times 945)-(1.1261 \times 0.8) \\
& =0.068 \mathrm{in} . \text { from the bottom of the flange. }
\end{aligned}
$$

\section{E. DISCUSSION}

It was found that the seal would operate satisfactorily over a wide range of pump speeds and sodium temperatures with a fixed coolant flowrate to both regions of the seal. It was necessary, however, to provide a source of heat to the lower region of the seal in order to obatin satisfactory performance at conditions of low shaft speed and low bulk sodium temperatures. At the se conditions, the heat generated by shaft rotation and that heat conducted to the seal from the bulk sodium was insufficient to keep the sodium molten in the lower seal region.

As previously stated, a thermocouple at the lower end of the seal skirt signaled the control unit of the liquid heater; the set point for this constant temperature at the bottom of the seal was $270^{\circ} \mathrm{F}$. This $270^{\circ} \mathrm{F}$ value was chosen in order to ensure molten sodium within the length of the lower region of the seal and to be above the cold-trapping temperature of the loop. It was observed that for any given set of operating conditions the solid-liquid interface was forced to remain at a given location. An increase or decrease in either shaft speed or bulk sodium temperature caused this interface location to rise and fall within the seal annulus. Because the friction heat of the shearing sodium varied with the interface position, the heat input to the liquid for the coil region varied also, resulting in the range of liquid inlet temperatures indicated in the second condition specified under optimum operation. 


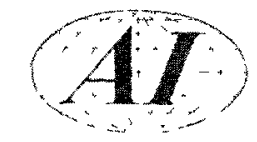

The scheme of heating the fluid circulated through the lower seal region was demonstrated to provide a very adequate, controlled, and stable operating seal. The problems of shaft seizure and oxide cold trapping in the seal were effectively eliminated by this operation.

It was also observed that a differential pressure in the excess of $15 \mathrm{psi}$ could not be maintained across the seal. At greater differential pressures gas would leak into the flowing sodium. 


\section{(A)}

\section{CASE FREEZE SEAL}

The construction of the shaft-freeze-seal test stand was performed to permit simulating conditions to be encountered in the pump. The outer casing of this test stand was equipped with a case-freeze-seal cooling jacket that was duplicated on the freeze-seal pump. It was with this prototype case freeze seal that the cooling requirements for the seal on the pump were established.

The only difference between the service requirements of these case seals was the pressure to be contained. In the pump this pressure went to nearly 70 psig while the freeze-seal test-stand pressure did not exceed 5 psig. Temperature distribution data and cooling requirements of the case freeze seal on the test stand were duplicated during operation of the pump.

\section{GAS SEAL}

Maintenance of an inert gas atmosphere within the casing of the pump required a gas seal for the pump shaft. This seal was to maintain a helium gas pressure of $5 \mathrm{psig}$ at $70^{\circ} \mathrm{F}$ whether the pump was running or not. An additional requirement was that no foreign matter be permitted to enter the pump either through or from the seal.

The original concept for the gas seal was a leather-lip seal running in castor oil over a 5-in.-diameter shaft. Early in the testing of this seal assembly, sufficient lip-seal failures occurred to warrant abandonment of the design. However, the suitability of the oil barrier concept of a shaft seal for gas was established.

A new seal assembly was built using magnetic face-type seals to hold the sealing oil. This seal, shown in Figure 16 was operated for a total of 6500 hours at speeds from 300 to $1180 \mathrm{rpm}$. During this period the seal successfully contained helium gas at $5 \mathrm{psig}$ and $70^{\circ} \mathrm{F}$. The seal was also subjected to a cycling test condition. 


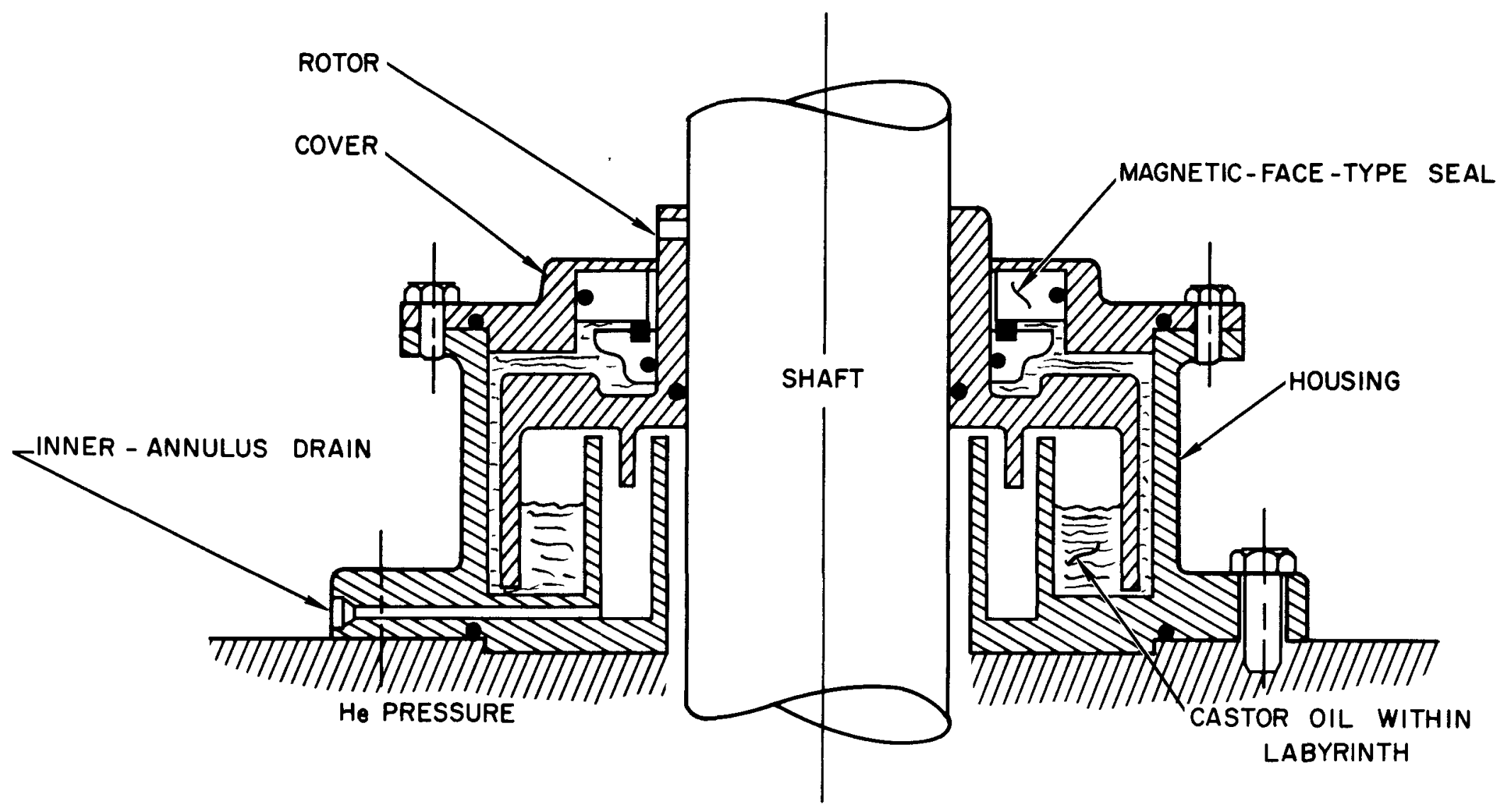

Figure 16. Gas Seal with Magnetic Faces 


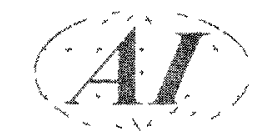

During the tests of the seal, efforts were made to measure helium leakage past the seal faces; no leakage was found, even when using a mass spectrometer. There was a small amount of oil leakage during the first 50 hours of operation. This leakage stopped after the faces became seated and did not reoccur during the test. 